\title{
Transgenic Expression of GM-CSF in T Cells Causes Disseminated Histiocytosis
}

Annemarie E. van Nieuwenhuijze, ${ }^{*}$ Elise Coghill, ${ }^{*}$ Daniel Gray, ${ }^{\dagger \dagger}$ Sandro Prato, ${ }^{* \dagger}$ Donald Metcalf, ${ }^{\dagger \S}$ Warren S. Alexander, ${ }^{\dagger \S}$ and Ian P. Wicks ${ }^{*} \uparrow$

From the Inflammation Division, * the Reid Rheumatology Laboratory, and the Divisions of Molecular Genetics of Cancer ${ }^{\ddagger}$ and Cancer and Haematology, ${ }^{\S}$ The Walter and Eliza Hall Institute of Medical Research, Parkville; the Department of Medical Biology, ${ }^{\dagger}$ University of Melbourne, Parkville; and the Rheumatology Unit, "Melbourne Health, PO Royal Melbourne Hospital, Parkville, Australia

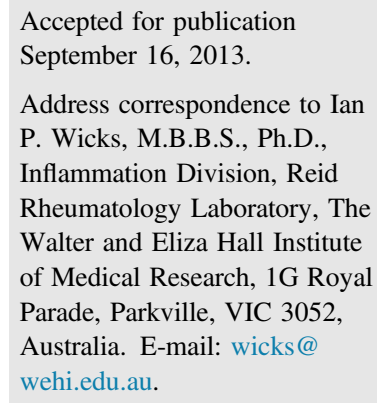

\begin{abstract}
Recent studies highlight surprising roles for granulocyte-macrophage colony-stimulating factor (GM-CSF) production by $T$ cells. T-cell-derived GM-CSF is required for the differentiation of monocyte-derived inflammatory dendritic cells during inflammation and for the pathogenicity of IL-17 producing T helper cells in autoimmunity. To gain further insight into these findings, we engineered in vivo overexpression of GM-CSF specifically in T cells, under the control of the Lck promoter. Lck-GM-CSF transgenic mice displayed a dramatic phenotype, characterized by splenomegaly, lymphadenopathy, thymic atrophy, and multiple abnormalities in blood cell populations. Thymocyte differentiation was severely affected, and there was a dramatic increase in regulatory $\mathrm{T}$ cells in the thymus and peripheral lymphoid organs. Lck-GM-CSF transgenic mice developed a disseminated histiocytosis and had increased circulating IL-17 producing Thelper cells-related cytokines. The pathological characteristics in Lck-GM-CSF transgenic mice resemble those of histiocytic human diseases, such as Langerhans cell histiocytosis. The etiology of many histiocytic disorders is unknown, but our findings suggest that over-production of GM-CSF by T cells could be a pathogenic factor and raise the possibility that GM-CSF may represent a novel therapeutic target. (Am J Pathol 2014, 184: 184-199; http://dx.doi.org/10.1016/j.ajpath.2013.09.014)
\end{abstract}

Although granulocyte-macrophage colony-stimulating factor (GM-CSF) was first described as a hematopoietic regulator that stimulates the expansion and differentiation of myeloid cells from bone marrow progenitors, it is recognized to have multiple functions. ${ }^{1}$ Interestingly, GM-CSF is produced by $\mathrm{T}$ cells and is transiently up-regulated in CD4 and CD8 $\mathrm{T}$ cells on stimulation through the T-cell receptor and costimulatory molecules, such as CD28. ${ }^{2}$ Recently, IL-23 and the transcription factor, retinoic acid receptor-related orphan receptor $\gamma \mathrm{t}(\mathrm{ROR}-\gamma \mathrm{t})$, were also found to drive GMCSF production by type 17 helper T cells (Th17). ${ }^{3}$ However, GM-CSF is unlikely to act directly on T cells, because these cells lack expression of the GM-CSF receptor. ${ }^{4,5}$

We recently reported that T-cell-derived GM-CSF plays a pivotal role in acute inflammatory peritonitis and during acute inflammatory arthritis. ${ }^{6}$ Production of GM-CSF by murine T cells was NF- $\kappa \mathrm{B} 1$ dependent, showing that transcription factors other than ROR- $\gamma \mathrm{t}$ can drive its production. T-cell-derived GM-CSF stimulated the differentiation of monocyte-derived inflammatory dendritic cells (MoDCs), most likely through the recruitment of monocyte precursors via chemokine ligand (CCL) 2 (monocyte chemoattractant protein-1). Other recent studies showed that GM-CSF promotes the induction and survival of Th17 cells via IL-6 and IL-23, and that GM-CSF is required for the pathogenicity of Th17 cells in experimental allergic encephalomyelitis. ${ }^{3,7}$ These discoveries, and the knowledge that GM-CSF-deficient mice are protected from several T-cell-dependent experimental disease models, ${ }^{8,9}$ suggest that GM-CSF might be of much greater importance for T-cell function than previously thought.

\footnotetext{
Supported by The Reid Charitable Trusts, National Health and Medical Research Council (NHMRC) Program grant 1016647, NHMRC Career Development Fellowship 637353 (D.G.), NHMRC Research Fellowship 575501 (W.S.A.), NHMRC Clinical Practitioner Fellowship 1023407 (I.P.W.), NHMRC Independent Research Institute Infrastructure Support Scheme grant 361646, the Australian Cancer Research Fund, Victorian State Government Operational Infrastructure Support grant, and the Cancer Council Victoria.
} 
Several models of transgenic overexpression of GM-CSF, either systemically ${ }^{10}$ or within nonhematopoietic tissues, have been previously described. ${ }^{11-14} \mathrm{~A}$ common feature of these models was local macrophage and dendritic cell (DC) recruitment/differentiation, with phenotypes including blindness due to accumulation of macrophages in the eye ${ }^{10}$ and the induction of autoimmune gastritis. ${ }^{14}$ To further dissect the role that T-cell-derived GM-CSF might play during inflammatory disease, we generated transgenic (TG) mice that overexpress GM-CSF specifically in T cells, using the murine Lck (p56lck) promoter. We found a dramatic phenotype in Lck-GM-CSF TG mice, characterized by splenomegaly, lymphadenopathy, and a remarkable infiltration of both lymphoid and nonlymphoid organs by histiocytes. Histiocytes possess hybrid characteristics of DCs, macrophages, and monocytes and are a classic feature of a range of poorly understood human diseases. Our study suggests that increased production of GM-CSF by T cells can drive histiocytosis and raise the possibility that GM-CSF inhibition may be beneficial in some of the histiocytic disorders.

\section{Materials and Methods}

\section{Production of Lck-GM-CSF TG Mice}

A 446-bp cDNA containing the coding sequence for murine GM-CSF (mGM-CSF) was inserted into the BamHI cloning site of the p1017S1 plasmid, which is flanked by the T-cell-specific murine $L c k$ proximal promoter and the human growth hormone poly-A tail (hGHpA). ${ }^{15} \mathrm{~A}$ linearized 5715-bp mGM-CSF transgene construct was injected into the pronucleus of fertilized C57BL/6 embryos. Two founder lines of $L c k$-GM-CSF TG mice were generated, with a different transgene copy number (as determined by Southern blot analysis). These founders were designated $L c k-\mathrm{GM}^{\mathrm{hi}}$ and $L c k-\mathrm{GM}^{\mathrm{lo}}$, respectively. TG mice were maintained in the heterozygous state on a C57BL/6 background.

\section{Southern Blot Analysis for Lck-GM-CSF Transgene Detection}

Genomic DNA from TG mice and wild-type (WT) littermate controls was purified from spleen by standard protocols and $5 \mu \mathrm{g}\left(L c k-\mathrm{GM}^{\mathrm{hi}}\right)$ or $10 \mu \mathrm{g}\left(L c k-\mathrm{GM}^{\mathrm{lo}}\right)$ of DNA was digested overnight with PstI at $37^{\circ} \mathrm{C}$. DNA was run on a $0.8 \%$ Tris-acetate-EDTA agarose gel, transferred to a Hybond $\mathrm{N}+$ nylon membrane, probed with a murine GM-CSF-specific ${ }^{32} \mathrm{P}$-deoxy-ATP-labeled 446-bp cDNA, and visualized by a Phospho Imager (BioRad, Gladesville, Australia).

\section{Quantitative RT-PCR for GM-CSF and ROR- $\gamma$ t Expression}

Total RNA was purified using RNeasy columns (Qiagen, Chadstone, Australia). cDNA was prepared by reverse transcription. Quantitative PCR was performed using an ABI Prism 7900 instrument (Applied Biosystems, Mulgrave, Australia) and SYBR Green reagent, according to the manufacturer's instructions (Qiagen). Results were normalized $\left(\Delta \mathrm{C}_{\mathrm{T}}\right)$ for hydroxymethylbilane synthase (hmbs) RNA content.

$\Delta \Delta \mathrm{C}_{\mathrm{T}}$ was calculated as $\Delta \mathrm{C}_{\mathrm{T}}(\mathrm{TG})-\Delta \mathrm{C}_{\mathrm{T}}(\mathrm{WT})$ for each sample.

Primer sequences were as follows: hmbs, 5'-CCTGGTTGTTCACTCCCTGA-3' (forward) and 5'-CAACAGCATCACAAGGGTTTT-3' (reverse); GM-CSF, $5^{\prime}$-CCAGCTCTGAATCCAGCTTCTC-3' (forward) and $5^{\prime}$-TCTCTCGTTTGTCTTCCGCTGT-3' (reverse); and ROR- $\gamma \mathrm{t}, \quad 5^{\prime}$-CCGCTGAGAGGGCTTCAC-3' (forward) and $5^{\prime}$-TGCAGGAGTAGGCCACATTACA-3' (reverse).

\section{Mice}

Ragl-deficient $\left(\right.$ Ragl $\left.^{-1-}\right)$ mice $^{16}$ and GM-CSF-deficient $\left(C s 2^{-1-}\right)$ mice $^{17}$ (both backcrossed to the C57Bl/6 background for 15 generations) were obtained from the Walter and Eliza Hall Institute (WEHI) animal services (Kew, Australia).

\section{Cell Culture}

Single-cell suspensions of pooled superficial lymph nodes (LNs), $\mathrm{LN}$ cells enriched for $\mathrm{CD} 4^{+} / \mathrm{CD} 8^{+}$cells by magnetic bead purification (Miltenyi Biotec, Macquarie Park, Australia), or thymocytes were cultured for 3 days at $0.5 \times$ $10^{6}$ cells per well in 96 -well culture plates at $37^{\circ} \mathrm{C}, 5 \% \mathrm{CO}_{2}$ in RPMI 1640 medium containing 10\% fetal calf serum, 20 $\mu \mathrm{mol} / \mathrm{L}$ 2-mercaptoethanol, $2 \mathrm{mmol} / \mathrm{L}$ glutamine, and 1 $\mathrm{mmol} / \mathrm{L}$ sodium pyruvate [complete medium $(\mathrm{CM})$ ]. Cells were stimulated on plates coated with $10 \mu \mathrm{g} / \mathrm{mL}$ anti-CD3 (clone 145-2C11; WEHI, Bundoora, Australia) and $2 \mu \mathrm{g} /$ $\mathrm{mL}$ anti-CD28 (clone 37.51; WEHI) monoclonal antibodies. For analysis of cytokine production by histiocytes, purified histiocytes (sorted by flow cytometry) were cultured for 10 hours in $\mathrm{CM}$ at $37^{\circ} \mathrm{C}, 5 \% \mathrm{CO}_{2}$.

\section{Immune Activation in Vivo}

Mice were injected with $100 \mu \mathrm{L}$ complete Freund's adjuvant (CFA; Sigma, Castle Hill, Australia) s.c. at the base of the tail. Control mice received PBS only. Seven days after CFA injection, superficial LNs were pooled, single-cell suspensions were prepared, and cells were restimulated in vitro with $50 \mathrm{ng} / \mathrm{mL}$ phorbolmyristate ester and $1 \mu \mathrm{g} / \mathrm{mL}$ ionomycin, or medium alone (un-stimulated), for 4 to 6 hours. Production of cytokines was determined by intracellular flow cytometry.

\section{Measurement of GM-CSF in Supernatants by Enzyme-Linked Immunosorbant Assay}

GM-CSF was measured in culture supernatants with the antibody pair, MP1-22E9 and biotinylated MP1-31G6 (both 
from BD Pharmingen, North Ryde, Australia), used according to the manufacturer's instructions.

\section{GM-CSF Bioassay}

The bioactivity of GM-CSF in fresh culture supernatant was tested using the GM-CSF-dependent FDC-P1 cell line (WEHI). Different concentrations of culture supernatant were added to 1000 FDC-P1 cells per well in the presence of $10 \mu \mathrm{g} / \mathrm{mL}$ neutralizing anti-IL-3 monoclonal antibody (clone MP2-8F8; WEHI). Cells were cultured in 96-well black optical culture plates (Thermo Scientific, Scoresby, Australia) for 2 days at $37^{\circ} \mathrm{C}, 10 \% \mathrm{CO}_{2}$, in Dulbecco's modified Eagle's medium containing $10 \%$ fetal calf serum. Proliferation was determined by adding $20 \mu \mathrm{L}$ per well resazurin (Sigma), and relative fluorescence units were measured at $535 \mathrm{~nm}$ (excitation) and $590 \mathrm{~nm}$ (emission) after 1, 2, 3, and 4 hours, respectively. Optimum fluorescence was obtained at 4 hours.

\section{Measurement of Multiple Analytes in Serum and Supernatants}

Serum or cell supernatant cytokines and chemokines were measured using the Bio-Plex mouse cytokine 23-plex panel (BioRad), used according to the manufacturer's instructions. The assay was read on a Bio-Plex 200 instrument and analyzed using Bio-Plex Manager software version 5.0 (BioRad, Gladesville, Australia).

\section{Antibodies for Flow Cytometry}

The following anti-mouse antibodies were used: Fc $\gamma$ receptor II/III (FcR Block) 2.4G2, CD3-biotin, CD4-fluorescein isothiocyanate (FITC), CD4-biotin, CD5-phycoerythrin (PE), CD8-Alexa700, CD8-biotin, CD11b-biotin, CD11c-FITC, CD24-PE.Cy5, CD25-PE, CD28-allophycocyanin (APC), CD44-FITC, CD103-Alexa700, CD115-FITC, CD205-PE, CD205-Alexa700, F4/80-FITC, F4/80-Alexa700, F4/80Alexa647, and $\mathrm{H}-2 \mathrm{~A}^{\mathrm{b}}$-biotin (all from WEHI); CD3-PE, CD207-Alexa647, Foxp3-APC, and Ly-6C-peridininchlorophyll-protein-cyanin5.5 (PerCp-Cy5.5) (all from eBioscience, Kensington, Australia); CD4-PerCp-Cy5.5, CD8-APC, CD8-APC-cyanin7 (APC-Cy7), CD11b-APC, CD11b-PE-Cy7, CD11c-PE, CD11c-APC, CD40-PE, CD43biotin, CD62L-APC, CD62L-APC.Cy7, CD64-PE, CD207Alexa647, GM-CSF-PE, IL-17A-APC, c-kit-APC, major histocompatibility complex (MHC) II-PE, NK1.1-biotin, Ly6C/ G-APC, Ly6G/C-PE, SiglecF-PE, and streptavidin-PE.Cy7 (all from BD Pharmingen); CD62L-PE-Texas Red (Invitrogen, Mulgrave, Australia); CD25-Alexa700, Ly6C-Pacific Blue (PacBlue), F4/80 PacBlue, Qa2-biotin, and T-cell receptor (TCR) $\beta$-PE.Cy7 (all from BioLegend, Karrinyup, Australia); and CX3CR1-PE, CCR2-APC, GM-CSF receptor (GM-CSFR) $\alpha-$ APC, and GM-CSFR $\beta$-APC (all from R\&D Systems, East Brisbane, Australia).

\section{Flow Cytometry}

Single-cell suspensions were prepared by passing organs through a $70-\mu \mathrm{m}$ cell strainer or by density gradient, as described later. Erythrocytes were lysed and cells were then washed with PBS containing $2 \mathrm{mmol} / \mathrm{L}$ EDTA and $1 \%$ fetal calf serum, treated with $10 \mu \mathrm{g} / \mathrm{mL} \mathrm{FcR}$ block and stained for flow cytometric analysis. Dead cells were excluded by propidium iodide, Fluoro-Gold, or Aqua live/dead (Invitrogen) staining. For intracellular staining of CD207, cells were treated with BD Cytofix/cytoperm (BD Biosciences, North Ryde, Australia), according to the manufacturer's instructions. For intracellular staining of IL-17A and GMCSF, cells were cultured for 4 to 6 hours in CM containing monensin and brefeldin (Golgistop, Golgiplug; BD Pharmingen), according to the manufacturer's instructions, followed by fixation in Cytofix/cytoperm, as previously described. An LSRII or LSR Fortessa instrument was used for flow cytometry (BD BioSciences). Histiocytes were sorted on an MoFlo automated cell sorter (BeckmanCoulter, Gladesville, Australia).

\section{Enrichment of DCs in Superficial LNs}

To enrich for DCs, light-density cells (LDCs) were purified as previously described. ${ }^{18}$ Cells were then stained for flow cytometric analysis of DC populations and subdivided into subpopulations based on surface and intracellular markers, as previously described. ${ }^{19,20}$

\section{Histological Analysis of Organs and Cytospins}

TG mice and WT littermates (two males and two females of each genotype at 6 weeks of age) were analyzed independently [through Australian Phenomics Network, by pathologist Dr. John Finnie, Adelaide, Australia, who is expert in the diagnosis of lymphoma; and at WEHI D.M.)]. Tissue sections $(5 \mu \mathrm{m}$ thick) were stained with $\mathrm{H} \& \mathrm{E}$ and scanned using a Zeiss Mirax digital slide scanner (Zeiss, North Ryde, Australia). Cells were cytospun onto polylysine-coated slides, stained with May-Grunwald Giemsa or Diff Quick stain (Lab Aids, Narrabeen, Australia), and examined using a Zeiss Axioplan 2 microscope, fitted with an AxioCam HR camera (Zeiss). AxioVision software version 3.1 (Zeiss) was used for all analyses of microscopic images.

\section{Differential Cell Counts of Blood and Peripheral Lymphoid Organs}

Blood was collected by retro-orbital bleed in sodium-EDTA tubes. Spleen, LN, and thymus were depleted of erythrocytes using ammonium chloride. Automated differential cell counts were performed using an ADVIA 120 instrument calibrated for murine hematopoietic cells (Siemens, Bayswater, Australia). 


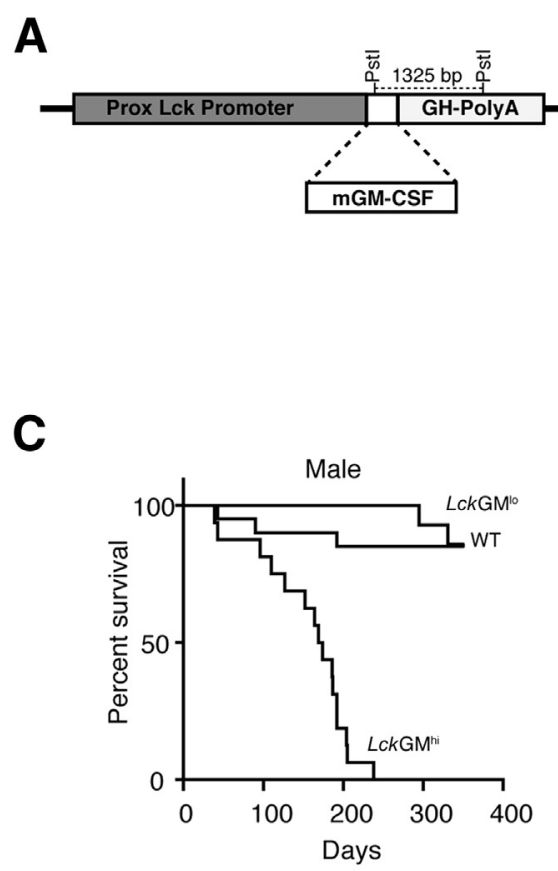

D

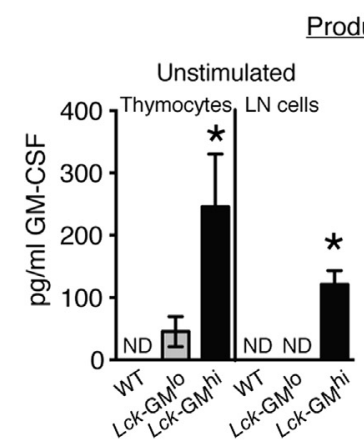

Production

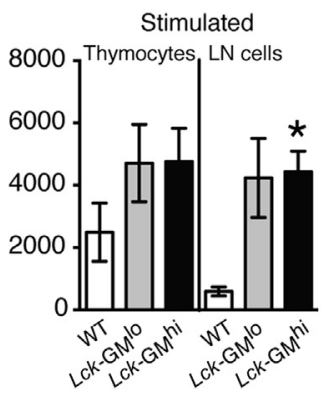

E
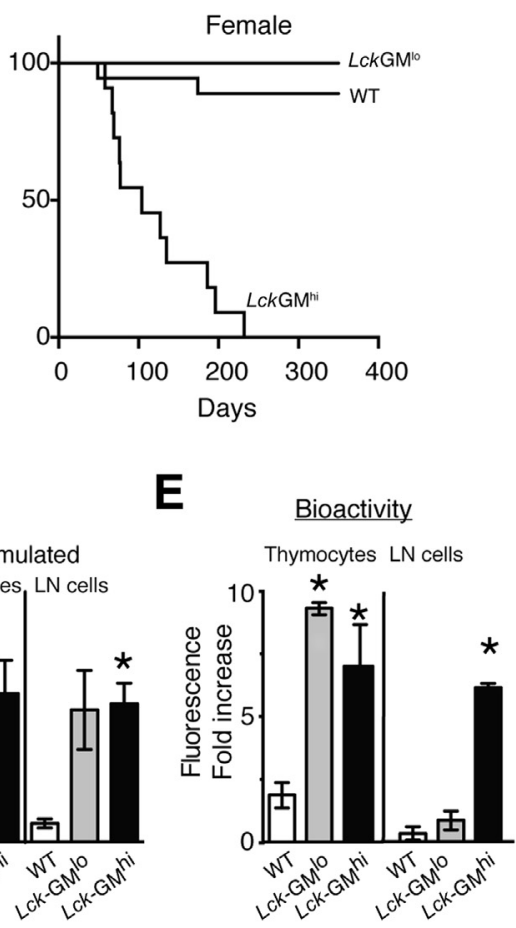

Supernatant

$\mathbf{F}$

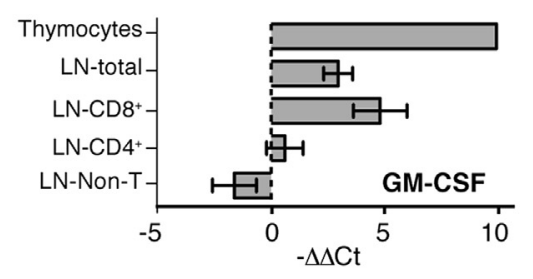

G

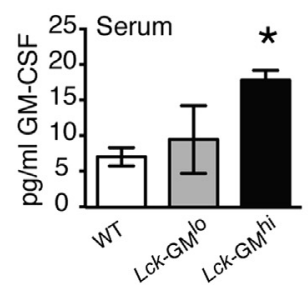

Figure 1 Generation of Lck-GM-CSF transgenic (TG) mice. A: DNA construct used to inject fertilized C57Bl/6 embryos. B: Agarose gel and Southern blot of genomic DNA from wild-type (WT) or Lck-GM-CSF TG mice probed with a ${ }^{32} \mathrm{P}$-labeled transgenespecific probe. C: Survival curves of male and female TG and WT mice ( $n=10$ to 20 mice per group). D: Production of GM-CSF by thymocytes or $\mathrm{LN}$ cells, unstimulated, or after 3 days of in vitro stimulation with anti-CD3 and anti-CD28 (CD3/ CD28). ND, not detected. Results are representative of two independent experiments ( $n=2$ mice per group). E: Bioactivity assay for GM-CSF. Proliferation was measured (by fluorescence) for FDC-P1 cells. Cells were incubated with 1:1000 diluted culture supernatant of anti-CD3/anti-CD28stimulated thymocytes or $\mathrm{CD}^{+} / \mathrm{CD}^{+} \mathrm{LN}$ cells, in the presence of anti-IL-3. Results are representative of two independent experiments $(n=2$ mice per group). F: Quantitative RT-PCR for GM-CSF on purified mRNA from thymocytes, total LN cells, sorted $\mathrm{LN} \mathrm{CD4}^{+}$or $\mathrm{CD}^{+}{ }^{+}$cells, and sorted $\mathrm{LN} \mathrm{CD}^{-}$ non- $T$ cells. $\Delta C_{T}$ was determined by normalization for expression of the hmbs gene. $\Delta \Delta C_{T}$ was defined as $\Delta C_{T}$ TG $-\Delta C_{T}$ of the corresponding WT cell population. Results are representative of two independent experiments $(n=1$ to 3 mice per group). Data are given as means \pm SEM. G: GM-CSF levels measured by BioPlex in serum from Lck-GM TG mice ( $n=16$ mice per group). ${ }^{*} P<0.05$ (unpaired $t$-test).

\section{In Vitro Clonogenic Analysis of Bone Marrow and Spleen Cells}

Colony formation by bone marrow and spleen cells was performed as previously described. ${ }^{21}$

\section{In Vivo Phagocytosis of Fluorescent Latex Beads}

Phagocytic cells were labeled in vivo, as previously described. ${ }^{22}$ Briefly, mice were injected i.v. with $250 \mu \mathrm{L}$ of $1: 25$ diluted 0.5 to $1.0 \mu \mathrm{mol} / \mathrm{L} \mathrm{YG} \mathrm{fluorescent} \mathrm{latex} \mathrm{beads} \mathrm{(PolySciences,}$ Gymea, Australia). Organs were analyzed for the presence of latex beads by flow cytometry, as previously described.

\section{Mixed Leukocyte Reaction}

Splenic antigen-presenting cell populations from $L c k-\mathrm{GM}^{\mathrm{h}}$ mice were sorted by flow cytometry, based on expression of $\mathrm{F} 4 / 80, \mathrm{CD} 11 \mathrm{~b}$, and CD11c. Where indicated, cells were fixed with $2 \%$ paraformaldehyde (PFA) for 30 minutes on ice. $\mathrm{CD}^{+}{ }^{+}$responder T cells from $\mathrm{BALB} / \mathrm{c}$ spleen were purified by magnetic bead sorting (AutoMacs; Miltenyi Biotec, North Ryde, Australia), using anti-CD3-PE-labeled antibody (BD Pharmingen) and anti-PE magnetic beads (Miltenyi Biotec), according to the manufacturer's instructions. Sorted TG splenocytes were co-cultured with $1 \times 10^{5} \mathrm{CD}^{+}$responder cells in a final volume of $200 \mu \mathrm{L}$ for 4 days at $37^{\circ} \mathrm{C}$ and $5 \%$ 
A

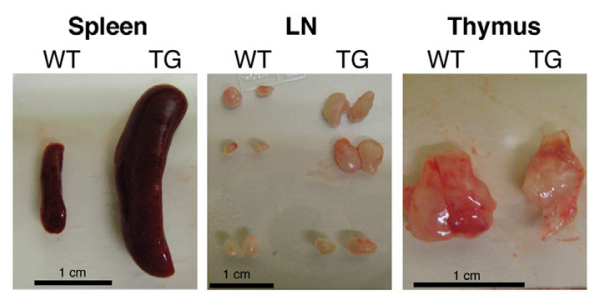

B

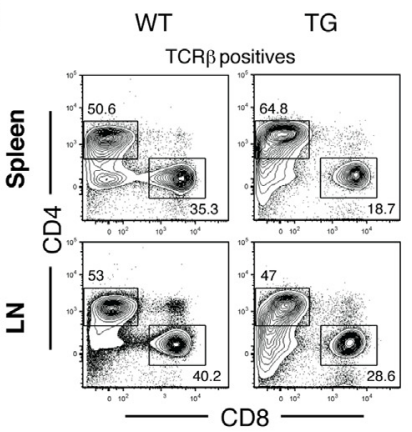

WT

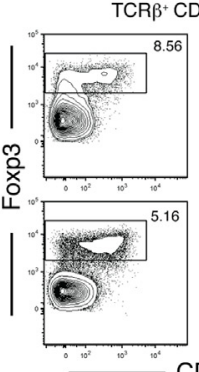

CD25
TG

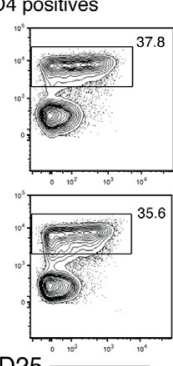

cell populations in spleen

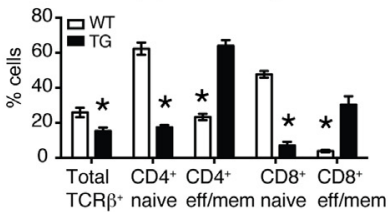

C
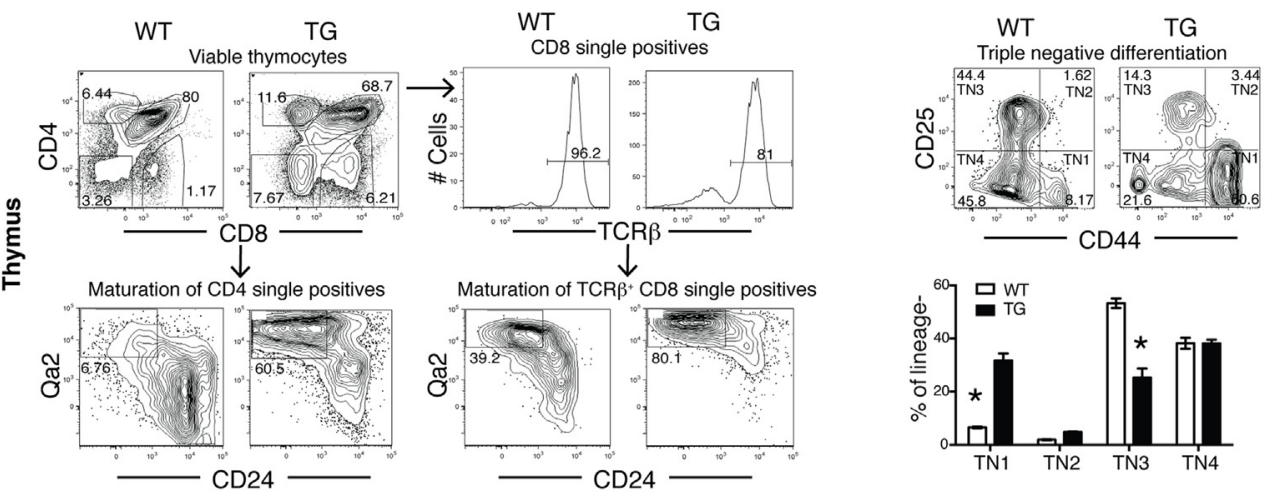

D
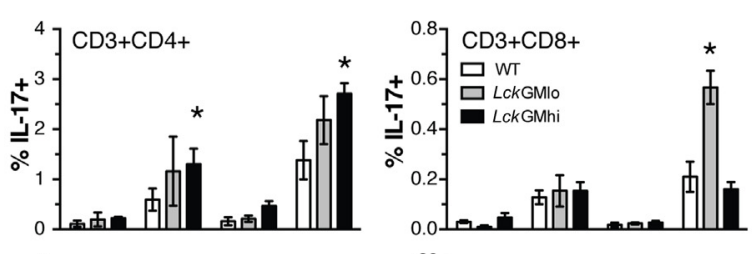

E
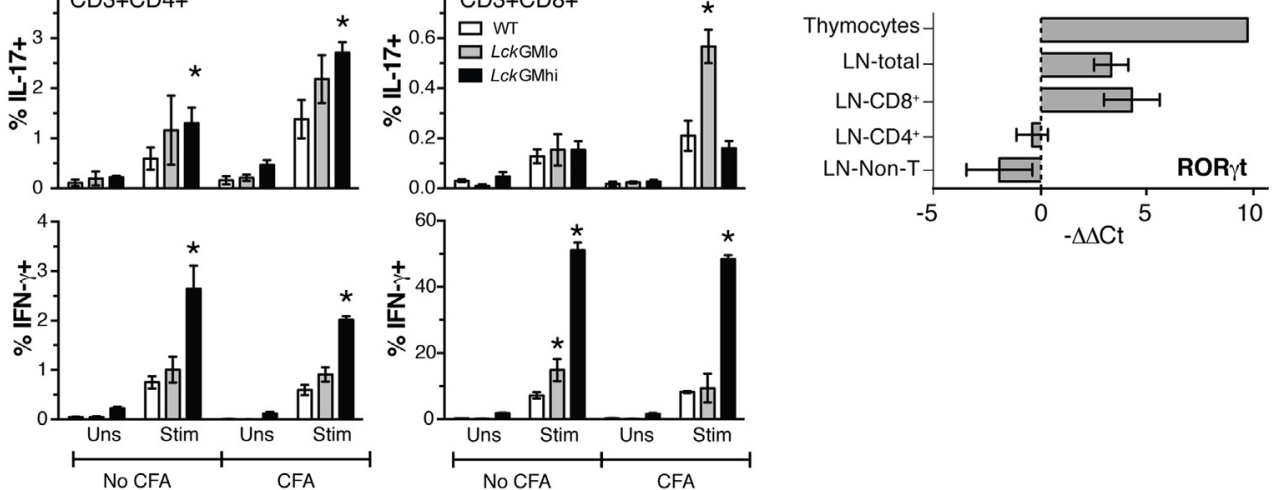

Figure 2 Splenomegaly, lymphadenopathy, thymic atrophy, perturbed CD8/CD4 T cells in the thymus, and increased ROR- $\gamma \mathrm{t}$ expression in thymocytes and T cells of Lck-GM-CSF TG mice. A: Photographs of spleen, LN, and thymus of $L c k-G M^{\text {hi }}$ TG and WT controls at 6 weeks of age. Scale bar $=1 \mathrm{~cm}$. B: Flow cytometric analysis of T-cell populations in spleen and LN. Single-cell suspensions were stained for TCR $\beta$, CD4, CD8, Foxp3, CD25, CD44, and CD62L. Cells were gated on TCR $\beta^{+}$, and Tregs were defined as $\mathrm{CD}^{+}{ }^{+}$Foxp $3^{+}$. Naïve T cells were defined as CD62 $\mathrm{L}^{\text {hi }} / \mathrm{CD} 44^{\text {lo }}$. Effector/memory (eff/mem) T cells (eff/mem) were defined as $\mathrm{CD} 62 \mathrm{~L}^{\mathrm{lo}} / \mathrm{CD} 44^{\mathrm{hi}}$. C: Single-cell suspensions from thymus were analyzed by flow cytometry for mature/immature $\mathrm{CD} 4^{+}$and $\mathrm{CD}^{+} \mathrm{T}^{\mathrm{T}}$-cell populations and triple-negative $\left(\mathrm{CD} 3 / \mathrm{CD} 4 / \mathrm{CD} 8^{-}\right)$differentiation. Mature $\mathrm{CD} 4^{+} \mathrm{T}$ cells were defined as $\mathrm{CD} 24^{-} \mathrm{Qa2} 2^{+}$. Mature $\mathrm{CD} 8^{+} \mathrm{T}$ cells were defined as $\mathrm{TCR}^{+} \mathrm{CD}^{-} 4^{-} \mathrm{Qa2} 2^{+}$. Lineage ${ }^{-} \mathrm{TN} 1, \mathrm{TN2}$, TN3, and TN4 were defined by the expression of CD44 and CD25, as shown. Data are given as means \pm SEM. D: Intracellular flow cytometry for the detection of IL-17 and IFN- $\gamma$ in $\mathrm{CD}^{+}$and $\mathrm{CD} 8^{+}$T cells after priming with CFA and restimulation of LN cells (phorbolmyristate ester/ionomycin) in vitro. E: Quantitative PCR for ROR- $\gamma$ t expression on RNA from purified thymocytes and LN cell populations. Expression in TG cells is shown as $-\Delta \Delta C_{T}$, normalized for expression of the $h m b s$ gene and normalized for ROR- $\gamma t$ expression of the corresponding WT cells. ${ }^{*} P<0.05$, Student's $t$-test. Stim, stimulated; Uns, unstimulated. 
Table 1 Weight and Absolute Numbers of Main Cell Subsets in Peripheral Lymphoid Organs

\begin{tabular}{|c|c|c|c|c|c|c|c|c|c|}
\hline \multirow[b]{2}{*}{ Variable } & \multicolumn{3}{|l|}{ Spleen } & \multicolumn{3}{|l|}{ Lymph nodes } & \multicolumn{3}{|l|}{ Thymus } \\
\hline & $\overline{L c k-G M^{h i}}$ & Lck-GMlo & WT & Lck-GM hi & Lck-GM ${ }^{\text {lo }}$ & WT & Lck-GM ${ }^{\text {hi }}$ & Lck-GMlo & WT \\
\hline $\begin{array}{l}\text { Weight } \\
\text { (grams) }\end{array}$ & $0.37 \pm 0.04$ & $0.11 \pm 0.01$ & $0.09 \pm 0.01$ & $0.10 \pm 0.02$ & $0.05 \pm 0.02$ & $0.03 \pm 0.004$ & $0.03 \pm 4.0$ & $0.06 \pm 0.01$ & $0.07 \pm 0.01$ \\
\hline WBC & $2920.54 \pm 396.78$ & $615.99 \pm 121.9$ & $479.64 \pm 53.88$ & $88.22 \pm 19.94$ & $16.50 \pm 4.8$ & $27.71 \pm 12.15$ & $21.59 \pm 6.69$ & $460.11 \pm 152.2$ & $401.18 \pm 93.9$ \\
\hline Neut & $103.97 \pm 20.13$ & $6.61 \pm 2.6$ & $3.28 \pm 0.77$ & $1.53 \pm 0.18$ & $0.64 \pm 0.18$ & $1.05 \pm 0.38$ & $0.70 \pm 0.22$ & $2.03 \pm 1.15$ & $1.54 \pm 0.66$ \\
\hline Lymph & $2023.61 \pm 191.75$ & $581.67 \pm 113.5$ & $463.15 \pm 51.01$ & $78.66 \pm 17.91$ & $15.08 \pm 4.93$ & $25.90 \pm 11.72$ & $18.59 \pm 5.77$ & $452.18 \pm 147.3$ & $395.51 \pm 91.26$ \\
\hline Mono & $69.53 \pm 16.24$ & $2.48 \pm 1.45$ & $1.32 \pm 0.41$ & $0.46 \pm 0.08$ & $0.27 \pm 0.0$ & $0.28 \pm 0.02$ & $0.16 \pm 0.12$ & $2.30 \pm 0.0$ & $0.64 \pm 0.56$ \\
\hline Eos & $530.78 \pm 185.04$ & $9.79 \pm 7.17$ & $3.01 \pm 0.43$ & $1.53 \pm 0.26$ & $1.59 \pm 1.04$ & $0.43 \pm 0.06$ & $0.77 \pm 0.12$ & $2.22 \pm 1.03$ & $1.74 \pm 0.6$ \\
\hline Baso & $105.42 \pm 13.66$ & $8.03 \pm 1.94$ & $6.40 \pm 1.16$ & $1.07 \pm 0.33$ & ND & $0.30 \pm 0.0$ & $0.87 \pm 0.25$ & $32.97 \pm 8.4$ & $28.95 \pm 5.33$ \\
\hline
\end{tabular}

Data are given as means $\pm \mathrm{SEM} \times 10^{-6} / \mu \mathrm{L} . n=4$ to 7 mice per group.

Baso, basophils; Eos, eosinophils; Lymph, lymphocytes; Mono, monocytes; ND, not detected (lower than the detection limit); Neut, neutrophils; WBC, white blood cell.

$\mathrm{CO}_{2}$. Tritiated thymidine, $1 \mu \mathrm{Ci}$ per well (Amersham BioSciences, Rydalmere, Australia), was added for the final 24 hours of culture; then, the supernatant was removed and cells were harvested onto glass-fiber filters for determination of tritiated thymidine incorporation using a Topcount scintillation counter (Perkin Elmer, Glen Waverley, Australia).

\section{Statistical Analysis}

$P$ values were determined by Mann-Whitney or Student's $t$-test, as indicated in the table and figure legends.

\section{Results}

\section{Generation and Validation of TG Mice}

TG mice were generated by injecting a construct comprising the murine proximal Lck promoter, mGM-CSF cDNA, and the hGHpA site into fertilized mouse embryos (Figure 1A). TG mice were identified by PCR using primers spanning the hGHpA/mGM-CSF junction. Two founders were selected, and transgenic offspring were confirmed by Southern blot analysis of genomic DNA (Figure 1B). One founder had a higher copy number of integrated transgene DNA, as judged by a more intense band for the transgene, despite lower loading of DNA (Figure 1B). Founders were, therefore, designated $L c k-\mathrm{GM}^{\mathrm{hi}}$ and $L c k-\mathrm{GM}^{\mathrm{lo}}$. The probe for GMCSF could also detect endogenous GM-CSF, which served as a loading control (Supplemental Figure S1). Survival analysis showed that $L c k-G_{M}{ }^{\text {hi }}$ mice appeared healthy for up to approximately 23 weeks, then gradually succumbed to splenomegaly and anemia (Figure 1C). Lck$\mathrm{GM}^{\mathrm{lo}}$ mice appeared healthy for $>12$ months and did not show increased mortality (Figure 1C).
To assay expression of the Lck-GM-CSF transgene, we cultured thymocytes and LN cells, with or without anti-CD3 and anti-CD28 antibodies. Three days later, GM-CSF levels in the supernatant were measured by enzyme-linked immunosorbent assay. Unstimulated thymocytes from both TG lines and unstimulated LN cells from the $L c k-G_{M}{ }^{\text {hi }}$ line showed increased production of GM-CSF, compared with WT cells. Stimulated thymocytes and LN cells from both transgenic lines showed markedly increased production of GM-CSF compared with WT cells (Figure 1D). To verify the bioactivity of GM-CSF produced by $L c k$-GM TG lymphocytes, these supernatants were diluted and added to GMCSF-dependent FDC-P1 cells. Possible interference from IL-3, which is also a growth factor for FDC-P1 cells, was blocked by the addition of neutralizing anti-IL-3 antibodies. FDC-P1 cells displayed a dose-dependent proliferation after incubation with T-cell supernatants, and this was greater with TG supernatants, demonstrating that the Lck-GM-CSF transgene produced functional protein (Figure 1E). Increased production of GM-CSF was also confirmed using quantitative RT-PCR on unstimulated $L c k-G^{\text {hi }}$ thymocytes and purified LN cell populations (Figure $1 \mathrm{~F}$ ). We found a clear increase in GM-CSF transcript (shown by an increase in $-\Delta \Delta \mathrm{C}_{\mathrm{T}}$ ) in thymocytes, total $\mathrm{LN}$ cells, and purified $\mathrm{CD}^{+}$ $\mathrm{LN}$ cells, a slight increase in purified $\mathrm{CD}^{+}{ }^{+} \mathrm{LN}$ cells, but no increase in $\mathrm{CD}^{-}$non-T cells. Together, these data show that Lck-GM mice express increased levels of functional GMCSF specifically in the T-cell lineage, with the strongest expression in thymocytes and peripheral $\mathrm{CD}^{+} \mathrm{T}$ cells.

\section{Lymphoid Abnormalities in Lck-GM-CSF TG Mice}

To determine the effects of increased T-cell-derived GMCSF on the lymphoid system, spleen, LN, and thymus were

Table 2 BioPlex Analysis of Serum Cytokines

\begin{tabular}{lllllllllll}
\hline & \multicolumn{1}{l}{ Analyte $(\mathrm{pg} / \mathrm{mL})$} \\
\cline { 2 - 10 } Mouse & $\mathrm{IL}-1 \beta$ & $\mathrm{IL}-2$ & $\mathrm{IL}-5$ & $\mathrm{IL}-6$ & $\mathrm{IL}-10$ & $\mathrm{IL}-17$ & $\mathrm{GM}-\mathrm{CSF}$ & CCL2 & CCL4 & TNF \\
\hline Lck-GM $^{\text {hi }}$ & $60.7 \pm 13.3$ & $24.1 \pm 2.9$ & $11.4 \pm 1.6$ & $26.8 \pm 12$ & $14.2 \pm 2.7$ & $7.3 \pm 1.4$ & $32.7 \pm 6.6$ & $254 \pm 39.4$ & $54.4 \pm 14$ & $372 \pm 68.4$ \\
WT & $22.6 \pm 5$ & $15.7 \pm 2.9$ & $6.7 \pm 0.8$ & $1.1 \pm 0.6$ & $10 \pm 3.3$ & $3.4 \pm 1.5$ & $10 \pm 3.3$ & $156 \pm 34$ & $19.3 \pm 8$ & $204 \pm 76.6$ \\
$P$ value $^{*}$ & 0.008 & 0.04 & 0.037 & 0.2 & 0.23 & 0.019 & 0.002 & 0.083 & 0.074 & 0.091 \\
\hline
\end{tabular}

Data are given as means \pm SEM. $n=12$ to 14 mice per group.

*Two-tailed Mann-Whitney test. 
harvested from 6-week-old WT and TG mice. Although TG mice and WT littermates had comparable body weights (data not shown), the weight, cellularity, and size of the spleen and LNs of $L c k-\mathrm{GM}^{\mathrm{hi}}$ mice were increased, compared with WT littermates (Figure 2 and Table 1). In contrast, these parameters were reduced in the thymus (Figure $2 \mathrm{~A}$ and Table 1). Some of these differences were also present (spleen and LN weight and cell numbers), but were less pronounced, in $L c k$ $\mathrm{GM}^{\mathrm{lo}}$ mice (Table 1), consistent with a lower transgene copy number (Figure 1B). Analysis of the main cell subsets (neutrophils, lymphocytes, monocytes, eosinophils, and basophils) in spleen and LNs revealed that the increase in total white cells of spleen and LNs included all subsets (Table 1). Eosinophil numbers were increased dramatically in the spleen, in accordance with other reports of GM-CSF overexpression. ${ }^{10}$ Likewise, the reduction in cellularity of the thymus was caused by decreased numbers of each subset, with the exception of monocytes (Table 1).

Analysis of T-cell subsets in these organs revealed relatively normal proportions of $\mathrm{CD} 4^{+}$and $\mathrm{CD} 8^{+} \mathrm{T}$ cells in the spleen and lymph nodes of $L c k-\mathrm{GM}^{\mathrm{hi}}$ mice (Figure 2B). However, a substantial increase in the number of $\mathrm{CD}^{+}{ }^{+} \mathrm{Foxp}^{+}{ }^{+}$regulatory $\mathrm{T}$ cells was observed in the $\mathrm{TG}$ mice, as well as a switch from naïve to effector/memory phenotype (Figure 2B), consistent with a systemic inflammatory process. ${ }^{23}$ In the TG thymus, thymocyte differentiation was severely impaired, with the proportion of immature double positive cells (DP, $\mathrm{CD} 4^{+} \mathrm{CD} 8^{+}$) decreased, whereas double negative cells (DN, $\left.\mathrm{CD} 4^{-} \mathrm{CD} 8^{-}\right)$and mature single positive subsets were increased (Figure 2C). To examine whether an early block in thymocyte differentiation might explain the lower numbers of cells, we analyzed progression through the CD3/CD4/CD8 triple-negative (TN) stages. There was an increase in TN1 cells, suggestive of an early differentiation block, but some progression through the TN stages was observed (Figure 2C), including $\beta$-selection [as judged by CD28 up-regulation in the TN3 subset (data not shown)]. The distribution of the semimature and mature single-positive thymocytes was severely altered, with large proportional increases of the most mature SP cells (defined as $\left.\mathrm{CD} 24^{\mathrm{lo}} / \mathrm{Q} 22^{\mathrm{hi}}\right)$, at the expense of the semimature SP cells. We also observed a substantial increase in the proportion of $\mathrm{CD} 4{ }^{+} \mathrm{Foxp}^{+}{ }^{+}$regulatory $\mathrm{T}$ cells in the thymus. In the context of markedly reduced thymocyte cellularity, these changes are consistent with a severe (but incomplete) block in thymic lymphopoiesis, with some recirculation of mature $\mathrm{T}$ cells.

\section{Increased Th17 Pathway Cytokines and Expression of} ROR- $\gamma \mathrm{t}$ in Thymocytes and LN Cells

In light of the recently reported role for GM-CSF in the differentiation of effector Th17 cells, ${ }^{3}$ we analyzed serum from mice aged between 6 and 12 weeks by Bio-Plex bead array (BioRad). Of the 23 cytokines and chemokines measured, IL-1 $\beta$, IL-2, IL-5, IL-12p40, GM-CSF, and IL-17A were markedly increased in TG mice, when
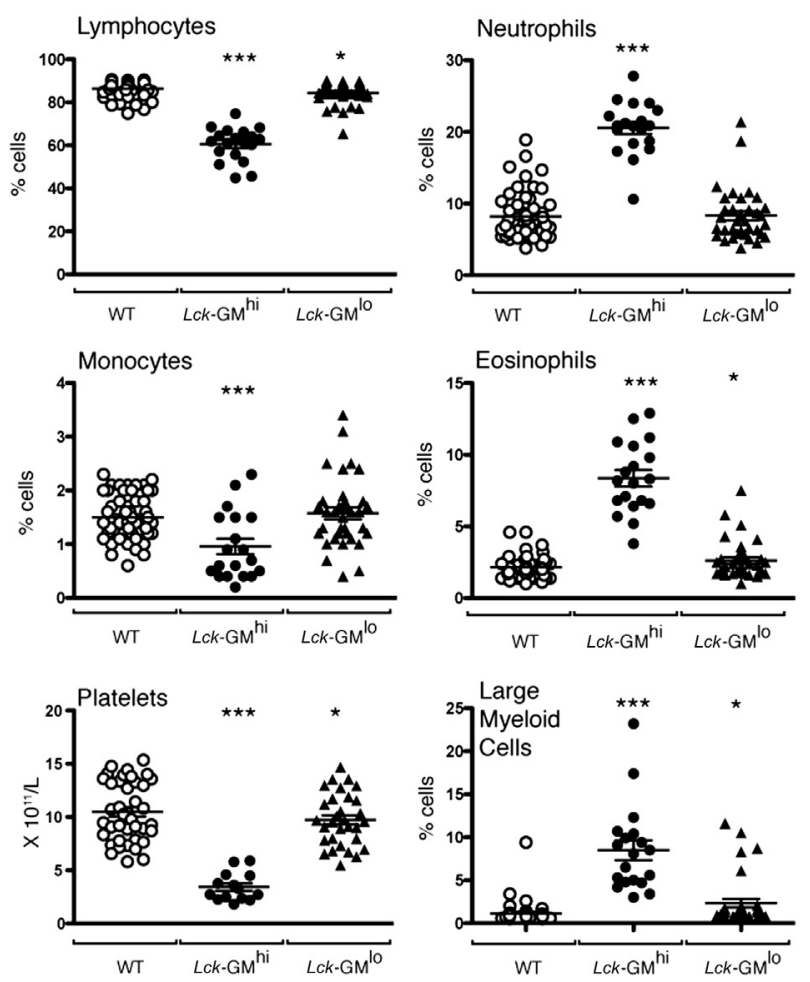

Figure 3 Lymphopenia, monocytopenia, thrombocytopenia, neutrophilia, eosinophilia, and an increase in large myeloid cells in peripheral blood of LCk-GM-CSF TG mice. Peripheral blood from TG mice and littermate controls between 6 and 12 weeks of age, analyzed by automated differential cell count. ${ }^{*} P<0.05,{ }^{* *} P<0.001$ (unpaired $t$-test).

compared with WT littermate controls (Table 2). All of these cytokines, except for IL-5, are implicated in the Th17 pathway. ${ }^{7}$ These findings suggest there might be enhanced Th17 $\left(\mathrm{CD}^{+}\right)$or $\mathrm{Tc} 17\left(\mathrm{CD}^{+}\right)$differentiation in the $\mathrm{Lck}$ GM-CSF TG mice. In contrast, serum concentrations of other cytokines and chemokines [IL-1 $\alpha$, IL-3, IL-4, IL-9, IL-10, IL-12(p70), IL-13, eotaxin, G-CSF, interferon (IFN) $\gamma$, keratinocytes, monocyte chemoattractant protein-1 (CCL2), macrophage inflammatory protein-1 $\alpha$ (CCL3), macrophage inflammatory protein- $1 \beta$ (CCL4), regulated on activation normal $\mathrm{T}$ cell expressed and secreted (CCL5), and tumor necrosis factor (TNF) $\alpha$ ] were no different from WT littermates (data not shown).

To formally assess Th17 and Tc17 differentiation in LckGM TG mice during global immune activation, we injected mice with CFA. LN cells were restimulated in vitro, and we compared the percentage of IL-17- and IFN- $\gamma-$ producing $\mathrm{CD}^{+}$and $\mathrm{CD}^{+}$cells (Figure 2D). The percentage of $\mathrm{CD} 4^{+}$ IL-17- or IFN- $\gamma-$ producing $\mathrm{T}$ cells in the TG mice was increased on in vitro restimulation, regardless of CFA injection. CFA injection boosted the number of $\mathrm{CD}^{+} \mathrm{IL}_{-}$ 17-producing T cells by approximately twofold. Surprisingly, when stimulated in this manner, the percentage of $\mathrm{CD} 8^{+} \mathrm{IL}-$ 17-producing $\mathrm{T}$ cells increased by approximately threefold in the $L c k-\mathrm{GM}^{\mathrm{lo}}$ mice when primed with CFA. This increase was not seen in the $L c k-\mathrm{GM}^{\mathrm{hi}}$ mice. In contrast, the percentage of 
Table 3 Colony Formation by Bone Marrow Cells

\begin{tabular}{|c|c|c|c|c|c|c|c|}
\hline \multirow[b]{2}{*}{ Mouse } & \multirow[b]{2}{*}{ Stimulus } & \multicolumn{6}{|c|}{ No. of colonies $/ 25,000$ bone marrow cells } \\
\hline & & Blast & G & GM & M & Eo & Meg \\
\hline \multirow[t]{5}{*}{ TG } & GM-CSF & 0 & $11 \pm 4$ & $2 \pm 1$ & $24 \pm 5$ & $1 \pm 1$ & 0 \\
\hline & M-CSF & 0 & $3 \pm 2$ & $1 \pm 1$ & $32 \pm 17$ & 0 & 0 \\
\hline & $\mathrm{IL}-3$ & $3 \pm 4$ & $13 \pm 6$ & $8 \pm 4$ & $12 \pm 3$ & $2 \pm 2$ & $3 \pm 1$ \\
\hline & SCF & $4 \pm 1$ & $6 \pm 2$ & $3 \pm 1$ & $2 \pm 1$ & 0 & 0 \\
\hline & Saline & 0 & 0 & 0 & 0 & 0 & 0 \\
\hline \multirow[t]{4}{*}{ WT } & GM-CSF & 0 & $27 \pm 4$ & $11 \pm 11$ & $45 \pm 6$ & $4 \pm 3$ & 0 \\
\hline & G-CSF & 0 & $16 \pm 5$ & 0 & 0 & 0 & 0 \\
\hline & M-CSF & 0 & $4 \pm 3$ & $11 \pm 1$ & $63 \pm 13$ & 0 & 0 \\
\hline & IL-3 & $2 \pm 1$ & $42 \pm 2$ & $22 \pm 1$ & $24 \pm 11$ & $5 \pm 0$ & $11 \pm 1$ \\
\hline
\end{tabular}

Data are given as means $\pm \mathrm{SD} . n=2$ mice per group.

Blast, blast cell, precursor cell; Eo, eosinophil; EPO, erythropoietin; G, granulocyte; GM, granulocyte/macrophage; M, macrophage; Meg, megakaryocyte; SCF, stem cell factor.

$\mathrm{CD}^{+}$IFN- $\gamma$-producing $\mathrm{T}$ cells was independent of CFA injection, and was increased by approximately twofold and 10fold in the $L c k-\mathrm{GM}^{\mathrm{lo}}$ and $L c k$-GM ${ }^{\mathrm{hi}}$ mice, respectively. We also assessed the production of GM-CSF in this experiment (Supplemental Figure S2). As expected, GM-CSF production was stronger in the $L c k$-GM ${ }^{\mathrm{hi}}$ mice, in particular in stimulated $\mathrm{CD}^{+} \mathrm{T}$ cells. This result suggests a link between IFN- $\gamma$ and GM-CSF production after stimulation.

Quantitative PCR for ROR- $\gamma \mathrm{t}$, which is a transcription factor required for Th17 differentiation, ${ }^{24}$ was performed. We found markedly increased ROR- $\gamma \mathrm{t}$ mRNA in TG thymocytes, total $\mathrm{LN}$ cells, and purified $\mathrm{CD}^{+} \mathrm{LN}$ cells (Figure 2E), suggesting an increased population of $\mathrm{Tc} 17$ cells in these organs (Figure 2E). Consistently, LN cells from both lines produced more IL-17, as well as GM-CSF, when stimulated with anti-CD3 and anti-CD28 (data not shown). Interestingly, the mRNA expression of ROR- $\gamma \mathrm{t}$ in purified TG CD4 ${ }^{+} \mathrm{LN}$ cells was unchanged. Although these cells displayed a clear increase in GM-CSF mRNA, this increase was modest when compared with purified $\mathrm{CD} 8^{+}$ LN cells (Figure 1E), suggesting a quantitative relationship between GM-CSF expression and ROR- $\gamma \mathrm{t}$ expression.

\section{Peripheral Blood Cell Populations Are Altered in Lck- GM-CSF TG Mice}

To analyze whether other hematopoietic cell types were affected by increased GM-CSF production by T cells, TG mice and WT littermates from both lines were bled at 6 weeks of age. Absolute numbers of total white blood cells were no different between WT and TG mice (data not shown); however, TG mice had a markedly increased percentages of neutrophils, eosinophils, and large myeloid cells (identified by the absence of the typical physical features of common blood cell populations) (Figure 3). Accordingly, there were reduced percentages of lymphocytes, monocytes, and platelets in TG mice. These changes in blood cell populations were observed in both lines, but were more pronounced in $L c k$-GM ${ }^{\mathrm{hi}}$ mice. The $L c k-\mathrm{GM}^{\mathrm{hi}}$ mice were also anemic (hematocrit, $60 \% \pm$ $0.8 \%$ for WT versus $46.3 \% \pm 6.4 \%$ for TG). We, therefore, chose $L c k-\mathrm{GM}^{\mathrm{hi}}$ mice for more detailed analysis.

\section{Decreased Colony-Forming Potential in Bone Marrow but Increased Colony-Forming Potential in Spleen in $\mathrm{Lck}_{\mathrm{G}} \mathrm{GM}^{\mathrm{hi}}$ Mice}

In light of the perturbations to TG myeloid populations, we performed colony-forming assays to assess myeloid precursors in the bone marrow and spleen (Table 3 and Table 4). TG bone marrow cells had decreased granulocyte, granulocyte/macrophage, macrophage, eosinophil, and megakaryocyte colony-forming potential (Table 3 ). Cell counts of bone marrow revealed normal cellularity, but increased percentages of mature neutrophils (data not shown). In contrast, TG splenocytes displayed increased colony-forming potential (Table 4), suggesting extramedullary myelopoiesis. We confirmed this result by manual differential cell counts of splenocytes (data not shown). Assays with saline alone did not yield any colonies from cultures of bone marrow or spleen.

\section{Altered Lymphoid Organ Architecture Due to Histiocytic Infiltration in $L c k-G M^{\text {hi }}$ Mice}

Histopathological analysis of the spleen and LNs of TG mice revealed marked effacement of the normal architecture 
Table 4

Colony Formation by Spleen Cells

\begin{tabular}{llllllll}
\hline & & \multicolumn{7}{l}{ No. of colonies/50,000 spleen cells } \\
\cline { 2 - 7 } Mouse & Stimulus & Blast & G & GM & M & Eo & Meg \\
\hline TG & GM-CSF & 0 & $2 \pm 1$ & $2 \pm 1$ & $5 \pm 4$ & 0 & 0 \\
& M-CSF & 0 & 0 & 0 & $5 \pm 4$ & 0 & 0 \\
& SCF + IL-3 & $20 \pm 0$ & $4 \pm 5$ & $2 \pm 2$ & $6 \pm 2$ & $1 \pm 1$ & $11 \pm 6$ \\
& + EP0 \\
& Saline & 0 & 0 & 0 & 0 & 0 & 0 \\
WT & GM-CSF & 0 & 0 & 0 & 0 & 0 & 0 \\
& M-CSF & 0 & 0 & 0 & $1 \pm 1$ & 0 & 0 \\
& SCF + IL-3 & $1 \pm 1$ & 0 & $1 \pm 0$ & $3 \pm 2$ & 0 & $5 \pm 1$ \\
& + EP0 & & & & & & \\
\hline & Saline & 0 & 0 & 0 & 0 & 0 & 0 \\
\hline
\end{tabular}

Data are given as means \pm SD. $n=2$ mice per group.

Blast, blast cell, precursor cell; Eo, eosinophil; EPO, erythropoietin; G, granulocyte; GM, granulocyte/macrophage; M, macrophage; Meg, megakaryocyte; SCF, stem cell factor.

by histiocyte-like cells, although a follicular pattern was still discernible (Figure 4). The spleen displayed an increase in nucleated erythroid cells, consistent with extramedullary erythropoiesis. Occasional multinucleated giant cells were observed, suggesting fusion of histiocytes and/or tissue macrophages. The TG thymus lacked normal lobes and had an atrophic appearance. There was effacement of the thymic medulla by histiocytes, as observed in spleen and LN, and the cortex was markedly reduced (Figure 4), consistent with the severe defects we observed in thymocyte differentiation. TG lungs showed multiple nodules, consisting of polymorphonuclear cells and histiocytes (Figure 4). There was an absence of mitotic figures in these nodules, arguing against neoplastic transformation. TG bone marrow (BM) showed a marked reduction in lymphocytes and an increase in granulocytes (Figure 4), in agreement with the differential cell counts. Nonlymphoid organs, including lung, kidney, and liver, showed varying degrees of infiltration by histiocytes and polymorphonuclear cells (Figure 4 and data not shown). In summary, the histological findings in Lck-GM-CSF TG mice were consistent with a disseminated histiocytosis.

\section{Lck-GM ${ }^{\text {hi }}$ Histiocytes Have Hybrid Features of Monocytes, Macrophages, and DCs}

Analysis of myeloid markers revealed dramatic expansion of $\mathrm{CD} 1 \mathrm{~b}^{+} \mathrm{F} 4 / 80^{\mathrm{int} /+}$ cells in the lymphoid organs of TG mice (Figure 5). In TG blood and BM, these cells were F4/ $80^{\text {lo }}$ (data not shown). This population could be further divided, based on CD11c staining and on morphological characteristics. The CD11 ${ }^{+}$population (histiocytes) was preferentially expanded in $L c k-\mathrm{GM}^{\mathrm{hi}}$ mice (Figure 5, B and C). Histiocytes were extensively immunophenotyped by flow cytometry. These cells also expressed CD115, MHCII, and low levels of CCR2 and CD62L, but not CD43, CD205, Ly6C, or CX3CR1; thus, they showed hybrid features of monocytes, macrophages, and DCs (Table 5). Histiocytes also expressed GM-CSFR $\alpha$ and GM-CSFR $\beta$ (Figure 5D) and intracellular CD207, which is a hallmark of Langerhans cells (Figure 5E). CD $11 \mathrm{~b}^{+} \mathrm{F} 4 / 80^{\mathrm{int} /+} \mathrm{CD} 11 \mathrm{c}^{-}$cells expressed the eosinophil marker, SiglecF, and were morphologically identical to eosinophils (Figure 5C).

We next evaluated the production of cytokines and chemokines by $L c k-\mathrm{GM}^{\mathrm{hi}}$ histiocytes, in vitro. $\mathrm{CD} 11 \mathrm{~b}^{+} \mathrm{F} 4 /$ $80^{\mathrm{int} /}{ }^{+} \mathrm{CD} 11 \mathrm{c}^{+}$histiocytes produced high levels of CCL4 and CCL5, suggesting that these cells might engender an
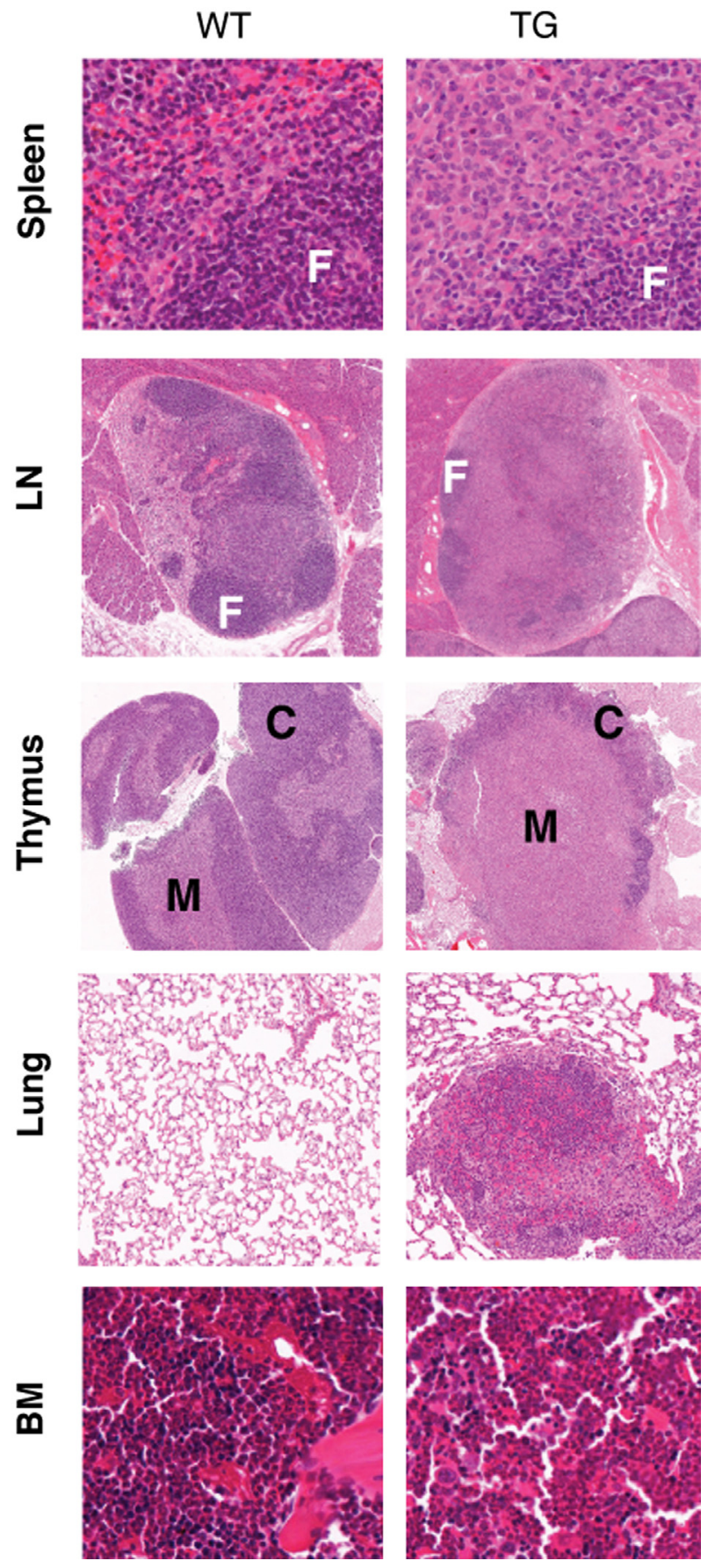

Figure 4 Histiocytic infiltrates in organs of Lck-GM-CSF TG mice. Organs and bone from $L c k-G M^{\text {hi }}$ mice were collected at 6 weeks of age, and sections were stained with H\&E. Original magnifications: $\times 50$ (LN and thymus); $\times 100$ (spleen, lung, and BM). C, cortex; F, follicle; M, medulla. 


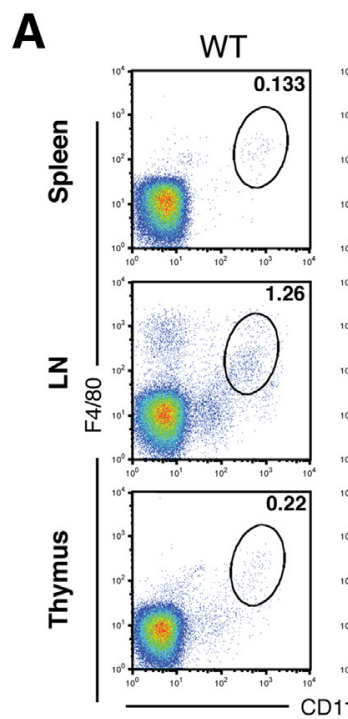

D

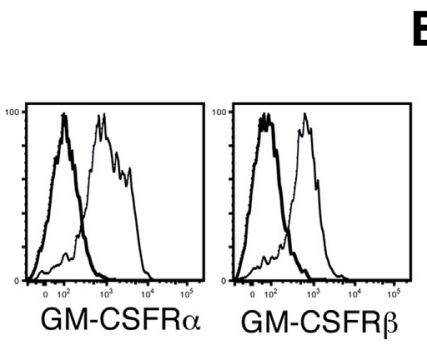

G

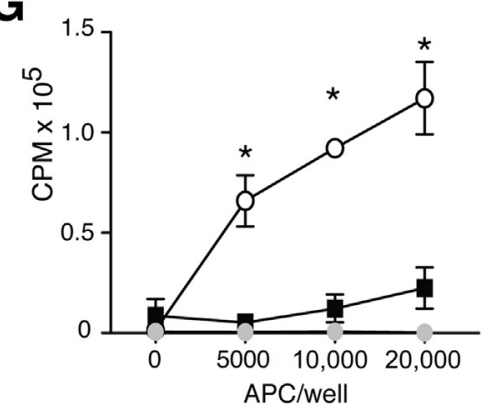

B
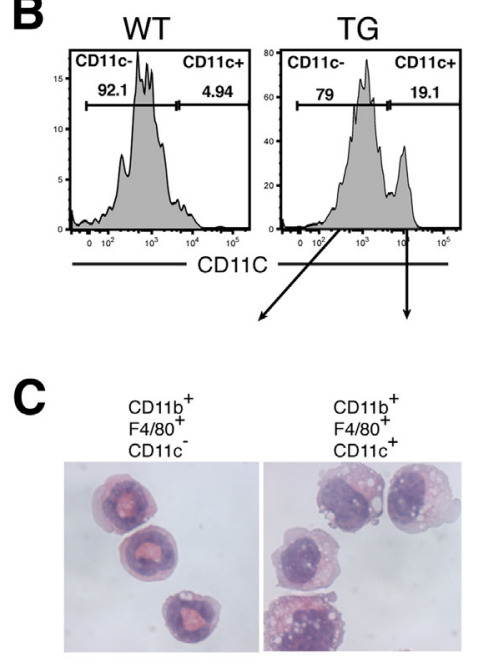

E

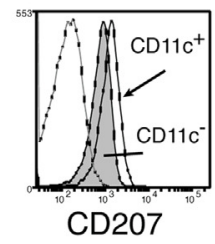

$\mathbf{F}$

H

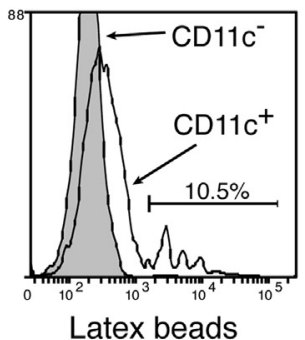

Figure 5 Characterization of histiocytes from TG mice. A: Flow cytometric analysis of CD11b and F4/80 expression on leukocytes from spleen, $L N$, and thymus of $L c k-G M^{\text {hi }}$ mice. B: Histiocytes can be distinguished from eosinophils by CD11c expression. Numbers represent percentage of live cells. C: Cytospins of $\mathrm{CD} 11 \mathrm{~b}^{+} \mathrm{F} 4 / 80^{\text {int } /+} \mathrm{CD} 11 \mathrm{c}^{-}$eosinophils and $\mathrm{CD}_{11 \mathrm{~b}^{+}} \mathrm{F} 4 / 80^{\mathrm{int} /+} \mathrm{CD} 11 \mathrm{C}^{+}$histiocyte cells, sorted from TG spleen. Cells were stained with MayGrunwald Giemsa stain. Original magnification, $\times 1000$. D: Detection of GM-CSFR $\alpha$ and $\beta$ on $\mathrm{CD} 11 \mathrm{~b}^{+} \mathrm{F} 4 / 80^{+}$cells from TG spleen (black line) by flow cytometry. E: Detection of CD207 (Langerin) on histiocytes $\left(C_{11}{ }^{+}\right.$, clear histogram) and eosinophils (CD11c ${ }^{-}$, shaded histogram) by flow cytometry. Control (gray line): unstained cells (D and $\mathbf{E}$ ). F: Analysis of cytokines and chemokines in culture supernatant from purified histiocytes from TG spleen by BioPlex bead array ( $n=2$ mice). G: Mixed leukocyte reaction of purified, unfixed histiocytes $\left(C D 11 c^{+}\right.$, white circles) or eosinophils (CD11 $\mathrm{c}^{-}$, black squares), or PFA-fixed histiocytes (gray circles), with purified splenic BALB/c $\mathrm{CD}^{+} \mathrm{T}$ cells. Proliferation after 4 days was measured by ${ }^{3} \mathrm{H}$ thymidine incorporation. Pooled data from two experiments shown ( $n=2$ mice per experiment). ${ }^{*} P<0.05$ (unpaired $t$-test). $\mathbf{H}$ : Uptake of fluorescent-labeled latex beads in vivo by $\mathrm{CD} 11 \mathrm{~b}^{+}$ $\mathrm{F} 4 / 80^{\mathrm{int} /+} \mathrm{CD} 11 \mathrm{C}^{+}$histiocytes. Beads were injected i.v., and spleen cells were analyzed by flow cytometry. CPM, counts per minute.

autocrine loop for recruitment of monocyte/macrophage and DC precursors (Figure 5F). In contrast, under these conditions, histiocytes did not produce nitric oxide (data not shown).

\section{Histiocytes from $L c k-G M^{\text {hi }}$ Mice Can Mature to Become Functional Antigen-Presenting Cells}

To determine whether histiocytes can stimulate naïve $\mathrm{T}$ cells, purified histiocytes and eosinophils were co-cultured with purified allogeneic $\mathrm{CD}^{+}$BALB/c T cells for 4 days. Histiocytes, but not eosinophils, could stimulate alloreactive T cells (Figure 5G). Histiocytes that were fixed with 2\% PFA before culture could not stimulate $\mathrm{T}$ cells, showing that cell maturation in vitro is required, as is the case for immature DCs. Immature DCs can also efficiently absorb antigens for processing and presentation. ${ }^{26} \mathrm{We}$, therefore, tested the ability of histiocytes to phagocytose latex beads in vivo (Figure $5 \mathrm{H}$ ).
Approximately $10 \%$ of histiocytes phagocytosed latex beads (Figure $5 \mathrm{H}$ ), whereas, as expected, eosinophils did not.

\section{Increased Langerhans DCs in LNs from $L c k-G M^{\text {hi }}$ Mice}

The human disease Langerhans Cell Histiocytosis (LCH) is characterized by tissue infiltration with Langerhans-type cells, commonly referred to as LCH cells, to distinguish them from Langerhans cells (LCs). ${ }^{27} \mathrm{LCH}$ cells express LC antigens, CD207 and CD1a, and the monocyte markers, CD68 and CD14. Expression of CD205, which is present on mature LCs, has been detected on tissue sections of human $\mathrm{LCH}$ lesions, but to our knowledge, the co-expression of CD207 and CD205 has not specifically been addressed in human LCH cells. ${ }^{27}$ In the mouse, functionally mature LCs in the LNs share a phenotype similar to human LCs and express CD207, CD11b, and CD205. ${ }^{20}$ TG histiocytes expressed low levels of $\mathrm{CD} 207$ and were negative for 


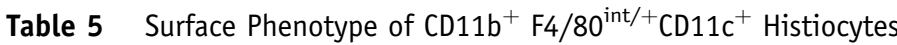

\begin{tabular}{|c|c|c|c|c|c|c|c|c|c|c|c|c|c|c|c|}
\hline \multirow[t]{2}{*}{ Cell type } & \multicolumn{15}{|c|}{ Membrane marker } \\
\hline & CD11b & CD11C & CD43 & CD62L & CD115 & CD205 & CD207 & Ly6C & $\mathrm{F} 4 / 80$ & CX3CR1 & CCR2 & MHCII & SiglecF & GM-CSFR $\alpha$ & GM-CSFR $\beta$ \\
\hline Histiocytes & + & + & - & $+/-$ & + & - & Lo & - & Int & - & Lo & + & - & + & + \\
\hline Eosinophils & + & - & $+/-$ & $+/-$ & $+/-$ & - & - & $+/-$ & Int & + & Lo & - & + & + & + \\
\hline Res mono & + & + & + & - & + & - & - & - & Lo & + & - & - & - & + & + \\
\hline Infl mono & + & - & + & + & + & - & - & + & Lo & + & + & - & - & + & + \\
\hline $\mathrm{cDC}$ & $+/-$ & ++ & - & - & - & - & - & - & - & Int & - & + & - & + & + \\
\hline Langerhans & + & + & - & - & + & ++ & ++ & - & - & - & + & ++ & - & + & + \\
\hline Infl mac & + & - & - & - & - & - & - & + & + & + & + & $+1-$ & + & + & + \\
\hline
\end{tabular}

Surface phenotypes of monocytes, DCs, and macrophages. Data obtained from previous studies. ${ }^{4,20,25}$

CDC, conventional DC; Infl mac, inflammatory macrophage; Infl mono, inflammatory monocyte; Int, intermediate levels; Lo, low levels; Res mono, resident monocyte; + , positive cells; ++ , high expressing positive cells; $+/-$, both positive and negative cells; - , negative cells.

CD205 (Figure 5D). To determine whether DC populations were skewed in TG mice, we enriched for DCs via a density gradient. The absolute number of light-density cells per $\mathrm{mg}$ of tissue was marginally increased in the TG mice, but this did not reach statistical significance (data not shown). However, DC populations of TG mice did differ from those in WT littermates (Figure 6). In the spleen, there was an increase in the percentage of CD11 $\mathrm{c}^{+} \mathrm{CD} 11 \mathrm{~b}^{-}$(resident DCs or migratory $\mathrm{CD} 11 \mathrm{~b}^{-} \mathrm{DCs}$ ) and $\mathrm{CD} 11 \mathrm{~b}^{+} \mathrm{CD} 11 \mathrm{c}^{+} \mathrm{DCs}$ in the light-density fraction (Figure 6A). With these markers, we could also distinguish $\mathrm{CD} 11 \mathrm{c}^{\text {int }} \mathrm{CD} 11 \mathrm{~b}^{+}$histiocytes/ histiocyte precursors (and possibly DC precursors), which were absent in the WT spleen (Figure 6A). The DCs were further analyzed for CD205 and CD207 expression (Figure 6A). This revealed the presence of Langerhans cells in the TG spleen, defined by the expression of CD205 and CD207. LCs are normally only present in LNs. ${ }^{20}$ In addition, TG mice displayed reduced $\mathrm{CD} 8^{+} \mathrm{DCs}$ in the spleen (Figure $6 \mathrm{~B}$ ). The proportion of $\mathrm{CD} 8^{-} \mathrm{DCs}$ was comparable to WT spleen. In the LNs, there was a slight reduction in $\mathrm{CD} 8^{+}$DCs and an increase in CD8 ${ }^{-}$DCs (Figure 6C). The percentage of Langerhans cells was variable, but there was a trend toward an increase of these cells. In contrast, $\mathrm{CD} 11 \mathrm{c}^{+} \mathrm{CD} 11 \mathrm{~b}^{-}$DCs were reduced in $C s f 2^{-/-}$mice (data not shown), consistent with a direct effect of GM-CSF on at least some DC populations in peripheral lymphoid organs.

\section{Histiocytosis Can Be Transferred to Lymphopenic Mice by Mature $L c k-G_{M}{ }^{h i} T$ Cells and Thymocytes}

To examine whether the histiocytosis observed in TG mice was directly due to over-production of GM-CSF by T cells, we transferred purified TG or WT $\mathrm{CD} 3{ }^{+} \mathrm{CD} 4^{+}\left(\mathrm{CD} 4^{+} \mathrm{T}\right.$ cells), $\mathrm{CD}^{+}{ }^{+} \mathrm{CD}^{+}{ }^{-}\left(\mathrm{CD} 8^{+} \mathrm{T}\right.$ cells), and $\mathrm{CD}^{-}$(non- $\left.\mathrm{T}\right) \mathrm{LN}$ cells, or unfractionated thymocytes, into $\mathrm{Ragl}^{-1-}$ mice. A week after transfer, mice that received $\mathrm{TG} \mathrm{CD} 4^{+}, \mathrm{CD} 8^{+} \mathrm{T}$ cells, or TG thymocytes had altered peripheral blood populations, which were similar to the changes found in TG mice. Recipient mice had a markedly increased percentage of large myeloid cells in the peripheral blood, which increased over time (Figure 7A). Histiocytes could be identified on histological analysis of spleens from mice injected with $\mathrm{TG} \mathrm{CD} 4^{+}$or $\mathrm{CD} 8^{+} \mathrm{T}$ cells (data not shown) and thymocytes, but not in spleens from mice that received non-T cells (Figure 7B). In addition, spleens from mice injected with $\mathrm{TG}$ thymocytes or $\mathrm{CD} 8^{+} \mathrm{T}$ cells were larger than spleens from mice injected with WT cells or TG CD $3^{-}$ non-T cells (Figure 7C). This effect was not seen when mice were injected with $\mathrm{CD} 4^{+} \mathrm{T}$ cells, most likely reflecting the difference in GM-CSF production between these cell types (Figure 1).

Differential cell counts of the spleen showed that the population of large myeloid cells was specifically expanded (Figure 7D), and these cells were $\mathrm{CD} 11 \mathrm{~b}^{+} \mathrm{F} 4 / 80^{+}$(shown for mice transferred with TG thymocytes in Figure 7E). In contrast, mice that received WT cells or TG non-T cells, and non-injected $\mathrm{Ragl}^{-/-}$mice (data not shown), did not accumulate histiocytes and had normal splenic architecture. These data demonstrate that histiocytosis is a cell-intrinsic consequence of the TG T cells.

\section{Discussion}

Recent studies highlight the importance of GM-CSF production by $\mathrm{T}$ cells in mediating immunity and inflammation. ${ }^{3,6,7}$ Following our earlier work, ${ }^{6}$ we hypothesized that increased production of GM-CSF by $\mathrm{T}$ cells might expand MoDCs during inflammation and cause increased differentiation of Th17 cells. We tested this hypothesis by overexpressing GM-CSF specifically in $\mathrm{T}$ cells, under the control of the $L c k$ promoter. We show strong expression of the Lck-driven GM-CSF transgene in the thymus and expression in peripheral lymphoid organs, in accordance with earlier reports using this promoter. ${ }^{28-30}$ Transgenic mice displayed a dramatic phenotype, characterized by splenomegaly, lymphadenopathy, thymic atrophy, and multiple abnormalities in thymic and blood cell populations. Lck-GM-CSF ${ }^{\text {hi }}$ mice had a decreased life span, which was due to splenomegaly (caused by histiocyte infiltration and extramedullary hematopoiesis) and anemia. Lck-GM-CSF TG mice developed disseminated histiocytosis, with an increased Foxp $^{+}$T-cell population, increased levels of 

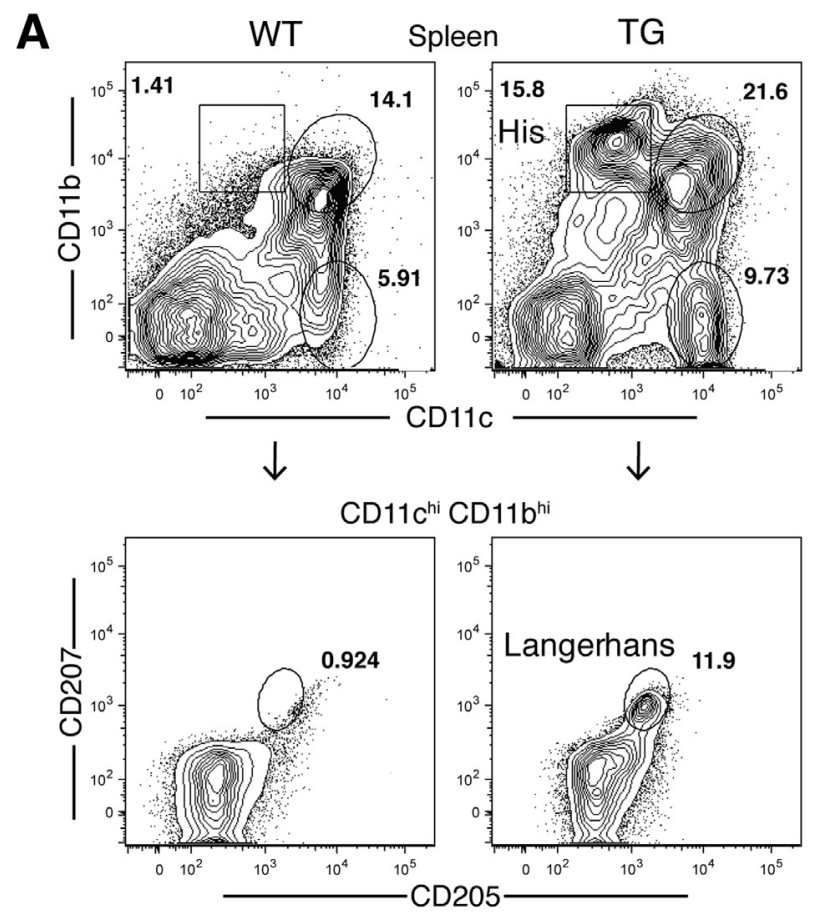

B

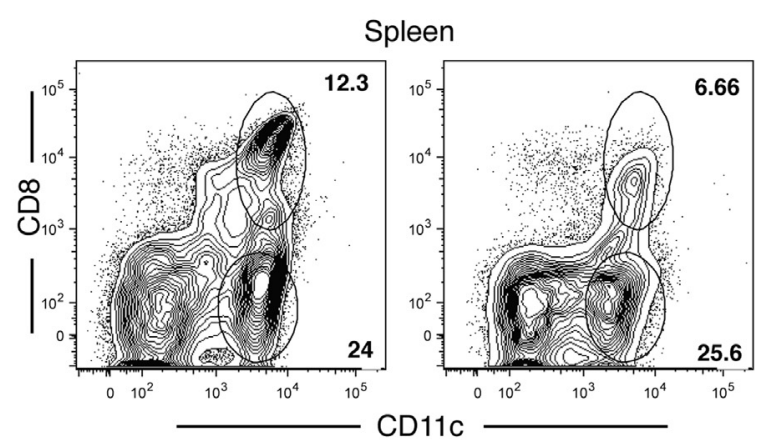

C

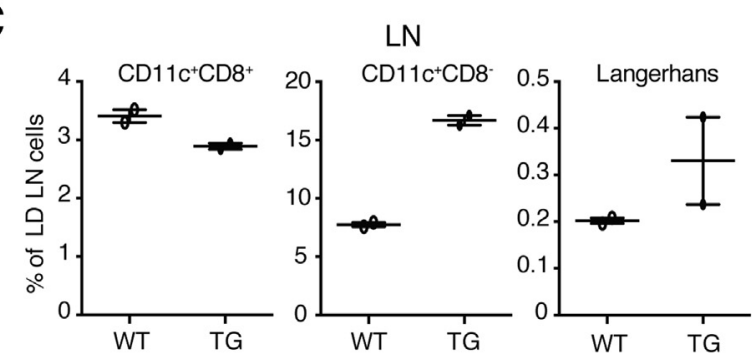

Figure 6 Flow cytometric analysis of DC populations. Light-density spleen cells were stained for CD11b and CD11C, CD8, CD205, and CD207. $\mathrm{CD} 11 \mathrm{C}^{\mathrm{hi}} / \mathrm{CD} 11 \mathrm{~b}^{\mathrm{hi}}$ cells were gated $(\mathbf{A})$ and further analyzed for the expression of CD8, CD205, and CD207 (B). C: Percentage of $\mathrm{CD}^{+}, \mathrm{CD}^{-}$ conventional DCs, and Langerhans DCs in WT and TG LN. Representative plots shown from two separate experiments. Mean and range from one experiment given in C. $n=2$ to 3 mice per genotype per experiment. His, histiocyte/histiocyte precursor population.

ROR- $\gamma \mathrm{t}$ mRNA, and increased circulating Th17-related cytokines. The increase in $\mathrm{CD} 4^{+} \mathrm{IL}_{1} 7^{+}$cells was even more obvious when $L c k$-GM-CSF mice were injected with CFA, linking GM-CSF production in the context of global immune activation with Th17 differentiation. Interestingly, basal expression of GM-CSF was strongest in thymocytes and $\mathrm{CD}^{+} \mathrm{T}$ cells, suggesting the increase in circulating Th17 cytokines in naive $L c k$-GM-CSF mice is most likely the result of more Tc17 cells, rather than Th17 cells. In vitro-stimulated $L c k-\mathrm{GM} \mathrm{TG} \mathrm{CD} 4^{+}$and $\mathrm{CD} 8^{+} \mathrm{T}$ cells produced high levels of IFN- $\gamma$, which was increased to up to approximately 10 -fold in the $L c k$-GM-CSF ${ }^{\text {hi }}$ mice compared with WT mice. These findings suggested that a link exists between the T-cell-derived production of GM-CSF and the production of IL-17 and IFN- $\gamma$ by T cells. In view of our findings in $\mathrm{CD} 8^{+} \mathrm{T}$ cells, it is possible that GM-CSF plays a role in the development of Tc17/IFN- $\gamma$ cells; these cells have been shown to have potent anti-tumor properties, which might explain the absence of tumors in the Lck-GM TG mice. ${ }^{31}$ In addition, infiltrating IFN- $\gamma-$ secreting T cells induce macrophage activation and inflammation, and play a significant role in target organ damage in autoimmunity. ${ }^{32}$ Increased IFN- $\gamma$ has also been implicated in the pathophysiological characteristics of some histiocytic disorders. ${ }^{33}$

Histiocytic disorders encompass a range of malignant and nonmalignant conditions that are incompletely understood, partly through lack of suitable animal models. LCH is a clonal proliferative disease, characterized by tissue infiltration with Langerhans-like cells (as recently reviewed ${ }^{34}$ ) and mutations in $B R A F .^{35,36}$ Not all cases of LCH are aggressive, and some have a better prognosis. ${ }^{34,37}$ A previous model of histiocytosis was generated by infecting mice with malignant histiocytosis sarcoma virus, leading to transitional macrophages/DC sarcomas. ${ }^{38}$ Another experimental model was induced by transgenic expression of the SV40 T oncogene in DCs. ${ }^{39}$ These mice developed infiltration of spleen, liver, bone marrow, thymus, and mesenteric lymph node with $\mathrm{CD} 11 \mathrm{c}^{+} \mathrm{CD} 8^{+} \mathrm{CD} 207^{+}$DCs, resembling the aggressive form of LCH. Mice in both these models invariably died early from the disease.

In TG mice, we found many infiltrating cells that expressed CD115, F4/80, and CD11b in the lymphoid organs, peripheral blood, BM, and nonlymphoid organs, such as the kidney, lung, and liver. These cells were phenotypically similar to immature monocytic Langerhans cell precursors. ${ }^{40}$ A subpopulation of these cells expressed CD11c and low levels of CD207, but not CD205. Although these markers are not exclusively expressed by LCs, ${ }^{19}$ the presence of CD11b suggests TG histiocytes are more similar to LCs than to other DC types. In WT mice, LCs are only found in the LNs, but we found mature $\mathrm{CD} 205^{+} \mathrm{CD} 207^{+}$ LCs in the spleen of TG mice. This finding may suggest that LCH in the TG mice might involve immature monocytic Langerhans cell precursors. Spleen and LN showed a dramatically increased size and cellularity, but with preserved follicular structure. High levels of chemokines, such as CCL2, CCL4, and CCL5, were produced by MoDCs ${ }^{6}$ and TG histiocytes, which could act as chemoattractants for histiocytic precursors to enter tissues and differentiate under the influence of local GM-CSF. The histiocytes of Lck-GM-CSF Tg mice express GM-CSFR $\alpha$ and $\beta$, CD207, and low levels of MHCII and can phagocytose latex beads 
A
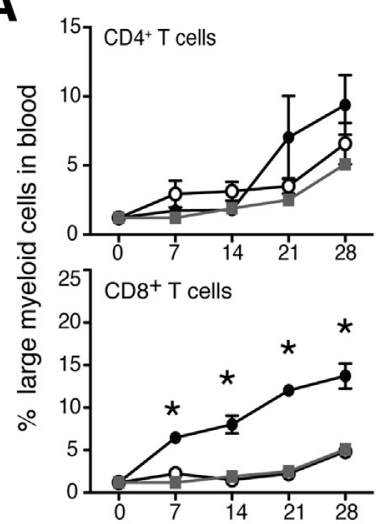
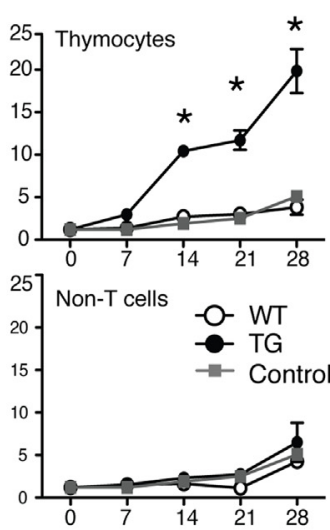

B

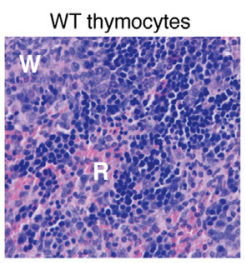

WT non-T cells

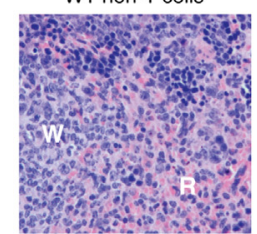

TG thymocytes

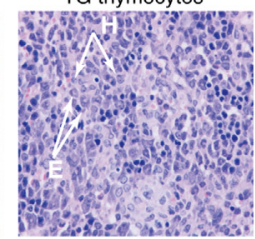

TG non-T cells

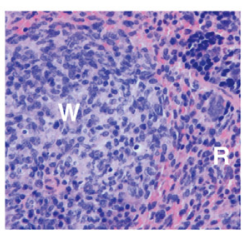

Days post-transfer
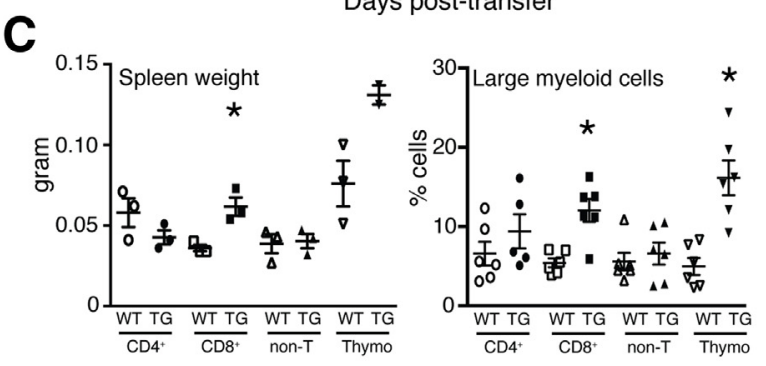

D
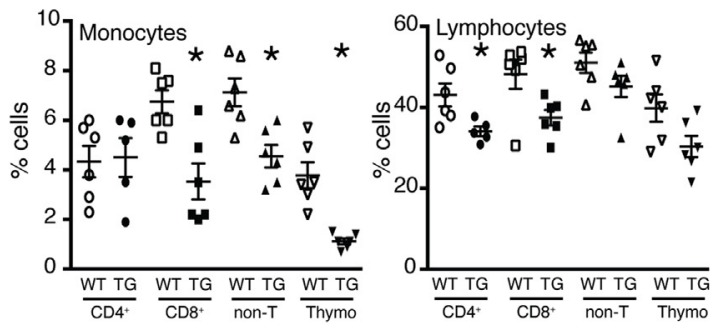

Figure 7 Histiocytosis can be transferred to Rag1 ${ }^{-/-}$mice by TG thymocytes and LN T cells. The $1 \times 10^{6}$ thymocytes or purified LN CD4 ${ }^{+} \mathrm{T}_{\text {cells, }}$ CD8 $8^{+} \mathrm{T}$ cells, or non-T $\left(\mathrm{CD}^{-}\right)$cells per mouse were transferred to Rag1 ${ }^{-/-}$mice by i.v. injection. A: Percentages of large myeloid cells were determined in peripheral blood by automated differential cell counts weekly after transfer ( $n=2$ to 3 mice per group per time point). B: H\&E-stained spleen sections from Rag1-/recipients receiving thymocytes or non-T cells. Original magnification, $\times 200 . n=3$ mice per group. Data from one experiment representative of two experiments is shown. E, eosinophils; $\mathrm{H}$, histiocytes; $\mathrm{R}$, red pulp; W, white pulp. C: Spleen weight and blood cell populations of Rag1 $1^{-/-}$mice on day 28 after transfer of donor cells and differential counts of splenocytes ( $n=2$ to 6 mice per group). D: Percentage of large myeloid cells in spleen determined by differential cell count on day 28 after transfer. Data are given as means \pm SEM ( $n=3$ mice per group). E: Flow cytometric analysis of CD11b and F4/80 expression on splenocytes from Rag1-/- mice on day 28 after transfer of WT or TG thymocytes. ${ }^{*} P<0.05$ ( $t$-test, Holm-Sidak method).

in vivo, and freshly isolated cells do not stimulate naïve $\mathrm{T}$ cells in mixed leukocyte reaction, suggesting an immature antigen-presenting cell phenotype. Human LCH histiocytes also resemble DCs held in an immature state in vivo by extrinsic factors, such as IL-10. ${ }^{41} \mathrm{We}$ show that, in vitro, Lck-GM-CSF-derived histiocytes can mature to become functional antigen-presenting cells, and we also observed marginally higher serum IL-10 in Lck-GM-CSF mice. Collectively, these observations in Lck-GM-CSF TG mice are also reminiscent of human LCH. The clinical and histological features and the absence of mitotic figures and of spontaneous cellular proliferation in our model thus suggest a nonneoplastic process in $L c k-\mathrm{GM}^{\mathrm{hi}}$ mice, which has many similarities to $\mathrm{LCH}$.

Transgenic expression of GM-CSF in nonhematopoietic tissue has been shown to cause local accumulation of macrophages and neutrophils. ${ }^{10-14}$ GM-CSF is a potent growth factor for eosinophils, ${ }^{42}$ and more of these cells were observed in another GM-CSF transgenic mouse. ${ }^{10} \mathrm{We}$ also found increased eosinophils and show that expression of GM-CSF in $\mathrm{T}$ cells causes accumulation of histiocytes, which has not been observed in previous GM-CSF transgenic mice. Interestingly, eosinophils and histiocytes can be found together in eosinophilic granuloma of bone. ${ }^{43} \mathrm{We}$, therefore, hypothesize that histiocytes differentiate in tissues that provide proximity to GM-CSF-producing T cells. This hypothesis is supported by earlier studies that showed increased serum levels of GM-CSF in patients with $\mathrm{LCH}$, expression of the GM-CSF receptor on $\mathrm{LCH}$ cells, and increased production of GM-CSF by $\mathrm{T}$ cells, macrophages, and $\mathrm{LCH}$ cells in $\mathrm{LCH}$ lesions. ${ }^{44-46}$

In contrast to increased cellularity in peripheral LNs, the thymi of $L c k-\mathrm{GM}^{\mathrm{hi}}$ mice were atrophic and had a severely reduced cortex. However, thymocyte differentiation appeared 
to still proceed, but was severely impaired. Increased local GM-CSF might favor retention of mature thymocytes in the medulla, or perhaps more likely, promote the recirculation of peripheral T cells. A direct effect of GM-CSF on thymocytes is unlikely due to the absence of GM-CSF receptors on T cells, ${ }^{47}$ and the observation that GM-CSF receptor-deficient mice did not display an overt T-cell phenotype. ${ }^{48}$ In the thymus and LN, we also observed a major increase in the proportion of $\mathrm{CD}^{+}{ }^{+} \mathrm{Foxp}^{+}{ }^{+}$regulatory $\mathrm{T}$ cells (Treg). Treg differentiation in the thymus requires both high-avidity TCR interactions and an additional signal from IL-2 or other $\gamma$-chain cytokines. ${ }^{49}$ Treg expansion in the $L c k$-GM TG mice is most likely due to increased recirculation from the periphery, but could be secondary to locally increased IL-2, $\mathrm{TNF}$, or transforming growth factor $\beta$ expression, caused by GM-CSF. Of potential relevance, we detected elevated IL-2 and slightly increased TNF in the serum. Interestingly, increased Treg numbers have been detected in lesions and peripheral blood from patients with $\mathrm{LCH}^{50}$ Tregs were detected in proximity of $\mathrm{LCH}$ cells, and it was suggested that LCH cells could be involved in Treg differentiation. ${ }^{50}$ Our findings in the $L c k$-GM TG thymus support this conclusion. We hypothesize that overproduction of GM-CSF by T cells induces the local differentiation of LCH cells, which produce cytokines or chemokines that promote Treg, Tc17, and Th17 differentiation. Expansion of Tregs might explain why Lck$\mathrm{GM}^{\text {hi }}$ mice are not overtly sick despite the infiltrates in many organs. Elevated serum levels of Th17-related cytokines (IL$1 \beta$, IL-2, and IL-12p40) are also consistent with a contribution of T-cell-derived GM-CSF to the Th17 pathway, ${ }^{7}$ and are most likely the result of increased GM-CSF production by $\mathrm{CD}^{+} \mathrm{T}$ cells, driving cytokine production by macrophages and DCs. However, whether the IL-17 family plays a direct role in the pathogenesis of $\mathrm{LCH}$ remains controversial. ${ }^{51,52}$

In the bone marrow, histiocytes might compete with myeloid progenitor cells for a common bone marrow niche, which might explain the decreased colony-forming potential we found from that site and the increased extramedullary hemopoiesis seen in the spleen. Administration of exogenous GM-CSF in itself does not cause histiocytosis, ${ }^{53}$ suggesting a requirement for direct cellular interaction. Our observation that transfer of $L c k$-GM TG T cells into lymphopenic recipients causes histiocytosis illustrates how this T-cell cytokine might affect myeloid differentiation. Our previous study showed that NF- $\mathrm{BB} 1-$ deficient mice, which had reduced GM-CSF production in $\mathrm{CD} 4^{+} \mathrm{T}$ cells, also had a decrease in inflammatory monocyte-derived DCs. ${ }^{6}$ Our results, therefore, shed new light on the possible in vivo consequences of GM-CSF production by $\mathrm{T}$ cells and are important for two reasons. First, the $L c k$-GM-CSF TG mice provide a novel murine model for histiocytosis. This heterogeneous group of human diseases has been difficult to understand and to treat. We provide evidence that overproduction of GM-CSF by $\mathrm{T}$ cells could be a pathogenic factor in histiocytic disorders, and LCH in particular. Second, and most important, our results raise the possibility that specific inhibitors of GM-CSF should be considered in the management of histiocytic disorders.

\section{Acknowledgments}

We thank the pathologists at the Australian Phenomics Network and Dr. John Finnie, in particular, for expert advice on pathology; Jason Corbin for help with differential cell counts; Ladina DiRago and Sandra Mifsud for help with colony-forming assays; Mark Chong for helpful discussions; Kelly Rogers for help with microscopy; Jacinta Grayden for genotyping and help with experiments; Rhiannon Jones for help with manuscript preparation; the WEHI Bioservices facility for animal husbandry; the WEHI Histology department; and the WEHI Flow Cytometry laboratory.

\section{Supplemental Data}

Supplemental material for this article can be found at http://dx.doi.org/10.1016/j.ajpath.2013.09.014.

\section{References}

1. Hamilton JA: Colony-stimulating factors in inflammation and autoimmunity. Nat Rev Immunol 2008, 8:533-544

2. Shi Y, Liu CH, Roberts AI, Das J, Xu G, Ren G, Zhang Y, Zhang L, Yuan ZR, Tan HSW, Das G, Devadas S: Granulocyte-macrophage colony-stimulating factor (GM-CSF) and T-cell responses: what we do and don't know. Cell Res 2006, 16:126-133

3. Codarri L, Gyülvészi G, Tosevski V, Hesske L, Fontana A, Magnenat L, Suter T, Becher B: ROR $\gamma$ t drives production of the cytokine GM-CSF in helper T cells, which is essential for the effector phase of autoimmune neuroinflammation. Nat Immunol 2011, 12:560-567

4. Rosas M, Gordon S, Taylor PR: Characterisation of the expression and function of the GM-CSF receptor $\alpha$-chain in mice. Eur J Immunol 2007, 37:2518-2528

5. Wada H, Noguchi Y, Marino MW, Dunn AR, Old LJ: T cell functions in granulocyte/macrophage colony-stimulating factor deficient mice. Proc Natl Acad Sci U S A 1997, 94:12557-12561

6. Campbell IK, van Nieuwenhuijze A, Segura E, O'Donnell K, Coghill E, Hommel M, Gerondakis S, Villadangos JA, Wicks IP: Differentiation of inflammatory dendritic cells is mediated by NF$\kappa \mathrm{B} 1$-dependent GM-CSF production in CD4 $\mathrm{T}$ cells. J Immunol 2011, 186:5468-5477

7. El-Behi M, Ciric B, Dai H, Yan Y, Cullimore M, Safavi F, Zhang G-X, Dittel BN, Rostami A: The encephalitogenicity of TH17 cells is dependent on IL-1- and IL-23-induced production of the cytokine GM-CSF. Nat Immunol 2011, 12:568-575

8. Campbell IK, Rich MJ, Bischof RJ, Dunn AR, Grail D, Hamilton JA: Protection from collagen-induced arthritis in granulocyte-macrophage colony-stimulating factor-deficient mice. J Immunol 1998, 161: 3639-3644

9. McQualter JL, Darwiche R, Ewing C, Onuki M, Kay TW, Hamilton JA, Reid HH, Bernard CC: Granulocyte macrophage colony-stimulating factor: a new putative therapeutic target in multiple sclerosis. J Exp Med 2001, 194:873-882

10. Lang RA, Metcalf D, Cuthbertson RA, Lyons I, Stanley E, Kelso A, Kannourakis G, Williamson DJ, Klintworth GK, Gonda TJ: Transgenic mice expressing a hemopoietic growth factor gene (GM-CSF) develop accumulations of macrophages, blindness, and a fatal syndrome of tissue damage. Cell 1987, 51:675-686 
11. Paine R 3rd, Wilcoxen SE, Morris SB, Sartori C, Baleeiro CE, Matthay MA, Christensen PJ: Transgenic overexpression of granulocyte macrophage-colony stimulating factor in the lung prevents hyperoxic lung injury. Am J Pathol 2003, 163:2397-2406

12. Krakowski M, Abdelmalik R, Mocnik L, Krahl T, Sarvetnick N: Granulocyte macrophage-colony stimulating factor (GM-CSF) recruits immune cells to the pancreas and delays STZ-induced diabetes. J Pathol 2001, 196:103-112

13. Breuhahn K, Mann A, Müller G, Wilhelmi A, Schirmacher P, Enk A, Blessing M: Epidermal overexpression of granulocyte-macrophage colony-stimulating factor induces both keratinocyte proliferation and apoptosis. Cell Growth Differ 2000, 11:111-121

14. Biondo M, Nasa Z, Marshall A, Toh BH, Alderuccio F: Local transgenic expression of granulocyte macrophage-colony stimulating factor initiates autoimmunity. J Immunol 2001, 166:2090-2099

15. Allen JM, Forbush KA, Perlmutter RM: Functional dissection of the lck proximal promoter. Mol Cell Biol 1992, 12:2758-2768

16. Mombaerts $\mathrm{P}$, Iacomini J, Johnson RS, Herrup K, Tonegawa S, Papaioannou VE: RAG-1-deficient mice have no mature B and T lymphocytes. Cell 1992, 68:869-877

17. Stanley E, Lieschke GJ, Grail D, Metcalf D, Hodgson G, Gall JA, Maher DW, Cebon J, Sinickas V, Dunn AR: Granulocyte/macrophage colony-stimulating factor-deficient mice show no major perturbation of hematopoiesis but develop a characteristic pulmonary pathology. Proc Natl Acad Sci U S A 1994, 91:5592-5596

18. Segura E, Albiston AL, Wicks IP, Chai SY, Villadangos JA: Different cross-presentation pathways in steady-state and inflammatory dendritic cells. Proc Natl Acad Sci U S A 2009, 106:20377-20381

19. Segura E, Villadangos JA: Antigen presentation by dendritic cells in vivo. Curr Opin Immunol 2009, 21:105-110

20. Villadangos JA, Heath WR: Life cycle, migration and antigen presenting functions of spleen and lymph node dendritic cells: limitations of the Langerhans cells paradigm. Semin Immunol 2005, 17: $262-272$

21. Metcalf D, Nicola NA: The clonal proliferation of normal mouse hematopoietic cells: enhancement and suppression by colonystimulating factor combinations. Blood 1992, 79:2861-2866

22. Tacke F, Alvarez D, Kaplan TJ, Jakubzick C, Spanbroek R, Llodra J, Garin A, Liu J, Mack M, van Rooijen N, Lira SA, Habenicht AJ, Randolph GJ: Monocyte subsets differentially employ CCR2, CCR5, and CX3CR1 to accumulate within atherosclerotic plaques. J Clin Invest 2007, 117:185-194

23. Wohlfert EA, Grainger JR, Bouladoux N, Konkel JE, Oldenhove G, Ribeiro CH, Hall JA, Yagi R, Naik S, Bhairavabhotla R, Paul WE, Bosselut R, Wei G, Zhao K, Oukka M, Zhu J, Belkaid Y: GATA3 controls Foxp $3^{+}$regulatory $\mathrm{T}$ cell fate during inflammation in mice. $\mathrm{J}$ Clin Invest 2011, 121:4503-4515

24. Ivanov II, Zhou L, Littman DR: Transcriptional regulation of Th17 cell differentiation. Semin Immunol 2007, 19:409-417

25. Geissmann F, Manz MG, Jung S, Sieweke MH, Merad M, Ley K: Development of monocytes, macrophages, and dendritic cells. Science 2010, 327:656-661

26. Wilson NS: Most lymphoid organ dendritic cell types are phenotypically and functionally immature. Blood 2003, 102:2187-2194

27. Geissmann F: Differentiation of Langerhans cells in Langerhans cell histiocytosis. Blood 2001, 97:1241-1248

28. Chen Y, Rosloniec E, Price J, Boothby M, Chen J: Constitutive expression of BCL-X(L) in the T lineage attenuates collagen-induced arthritis in Bcl-X(L) transgenic mice. Arthritis Rheum 2002, 46: $514-521$

29. Haynes NM, Allen CDC, Lesley R, Ansel KM, Killeen N, Cyster JG: Role of CXCR5 and CCR7 in follicular Th cell positioning and appearance of a programmed cell death gene-1high germinal centerassociated subpopulation. J Immunol 2007, 179:5099-5108

30. Zimmer MI, Colmone A, Felio K, Xu H, Ma A, Wang C-R: A celltype specific CD1d expression program modulates invariant NKT cell development and function. J Immunol 2006, 176:1421-1430
31. Satoh T, Tajima M, Wakita D, Kitamura H, Nishimura T: The development of IL-17/IFN- $\gamma$-double producing CTLs from Tc17 cells is driven by epigenetic suppression of Socs 3 gene promoter. Eur J Immunol 2012, 42:2329-2342

32. Hu X, Ivashkiv LB: Cross-regulation of signaling pathways by interferon- $\gamma$ : implications for immune responses and autoimmune diseases. Immunity 2009, 31:539-550

33. Jordan MB, Hildeman D, Kappler J, Marrack P: An animal model of hemophagocytic lymphohistiocytosis (HLH): CD8 + T cells and interferon gamma are essential for the disorder. Blood 2004, 104:735-743

34. Ng-Cheng-Hin B, O'Hanlon-Brown C, Alifrangis C, Waxman J: Langerhans cell histiocytosis: old disease new treatment. Q J Med 2011, 104:89-96

35. Sahm F, Capper D, Preusser M, Meyer J, Stenzinger A, Lasitschka F, Berghoff AS, Habel A, Schneider M, Kulozik A, Anagnostopoulos I, Müllauer L, Mechtersheimer G, von Deimling A: BRAFV600E mutant protein is expressed in cells of variable maturation in Langerhans cell histiocytosis. Blood 2012, 120:e28-e34

36. Haroche J, Charlotte F, Arnaud L, von Deimling A, HéliasRodzewicz Z, Hervier B, Cohen-Aubart F, Launay D, Lesot A, Mokhtari K, Canioni D, Galmiche L, Rose C, Schmalzing M, Croockewit S, Kambouchner M, Copin MC, Fraitag S, Sahm F, Brousse N, Amoura Z, Donadieu J, Emile JF: High prevalence of BRAF V600E mutations in Erdheim-Chester disease but not in other non-Langerhans cell histiocytoses. Blood 2012, 120:2700-2703

37. Minkov M: Multisystem Langerhans cell histiocytosis in children: current treatment and future directions. Paediatr Drugs 2011, 13:75-86

38. Leenen PJ, Bechan GI, Melis M, den Broeder BJ, Löhler J, Egeler RM: Heterogeneity in a mouse model of histiocytosis: transformation of Langerin + dendritic cells, macrophages, and precursors. J Leukoc Biol 2010, 87:949-958

39. Steiner QG, Otten LA, Hicks MJ, Kaya G, Grosjean F, Saeuberli E, Lavanchy C, Beermann F, McClain KL, Acha-Orbea H: In vivo transformation of mouse conventional CD8+ dendritic cells leads to progressive multisystem histiocytosis. Blood 2008, 111:2073-2082

40. Ginhoux F, Tacke F, Angeli V, Bogunovic M, Loubeau M, Dai X-M, Stanley ER, Randolph GJ, Merad M: Langerhans cells arise from monocytes in vivo. Nat Immunol 2006, 7:265-273

41. Laman J: Langerhans-cell histiocytosis "insight into DC biology". Trends Immunol 2003, 24:190-196

42. Metcalf D, Begley CG, Johnson GR, Nicola NA, Vadas MA, Lopez AF, Williamson DJ, Wong GG, Clark SC, Wang EA: Biologic properties in vitro of a recombinant human granulocyte-macrophage colony-stimulating factor. Blood 1986, 67:37-45

43. Jaffe R, Weiss L, Facchetti F: Tumours derived from Langerhans cells. WHO classification of tumours of haematopoietic and lymphoid tissues IARC Press, Lyon, France. 2008, 358-360.

44. Emile JF, Tartour E, Brugières L, Donadieu J, Le Deist F, Charnoz I, Fischer A, Fridman WH, Brousse N: Detection of GM-CSF in the sera of children with Langerhans' cell histiocytosis. Pediatr Allergy Immunol 1994, 5:162-163

45. Emile JF, Fraitag S, Andry P, Leborgne M, Lellouch-Tubiana A, Brousse N: Expression of GM-CSF receptor by Langerhans' cell histiocytosis cells. Virch Arch 1995, 427:125-129

46. Egeler RM, Favara BE, van Meurs M, Laman JD, Claassen E: Differential in situ cytokine profiles of Langerhans-like cells and T cells in Langerhans cell histiocytosis: abundant expression of cytokines relevant to disease and treatment. Blood 1999, 94:4195-4201

47. Hercus TR, Thomas D, Guthridge MA, Ekert PG, King-Scott J, Parker MW, Lopez AF: The granulocyte-macrophage colony-stimulating factor receptor: linking its structure to cell signaling and its role in disease. Blood 2009, 114:1289-1298

48. Robb L, Drinkwater CC, Metcalf D, Li R, Köntgen F, Nicola NA, Begley CG: Hematopoietic and lung abnormalities in mice with a null mutation of the common beta subunit of the receptors for granulocyte-macrophage colony-stimulating factor and interleukins 3 and 5. Proc Natl Acad Sci U S A 1995, 92:9565-9569 
49. Hsieh CS, Lee HM, Lio CWJ: Selection of regulatory T cells in the thymus. Nat Rev Immunol 2011, 12:157-167

50. Senechal B, Elain G, Jeziorski E, Grondin V, Patey-Mariaud de Serre N, Jaubert F, Beldjord K, Lellouch A, Glorion C, Zerah M, Mary P, Barkaoui M, Emile JF, Boccon-Gibod L, Josset P, Debré M, Fischer A, Donadieu J, Geissmann F: Expansion of regulatory T cells in patients with Langerhans cell histiocytosis. PLoS Med 2007, 4: e253

51. Coury F, Annels N, Rivollier A, Olsson S, Santoro A, Speziani C, Azocar O, Flacher M, Djebali S, Tebib J, Brytting M, Egeler RM,
Rabourdin-Combe C, Henter J-I, Arico M, Delprat C: Langerhans cell histiocytosis reveals a new IL-17A-dependent pathway of dendritic cell fusion. Nat Med 2007, 14:81-87

52. Allen CE, McClain KL: Interleukin-17A is not expressed by CD207+ cells in Langerhans cell histiocytosis lesions. Nat Med 2009, 15:483-484

53. Metcalf D, Begley CG, Williamson DJ, Nice EC, De Lamarter J, Mermod JJ, Thatcher D, Schmidt A: Hemopoietic responses in mice injected with purified recombinant murine GM-CSF. Exp Hematol 1987, 15:1-9 